\title{
Altered BOLD signal variation in Alzheimer's disease and frontotemporal dementia
}

\author{
Timo Tuovinen $^{* 1,2}$, Janne Kananen ${ }^{1,2}$, Riikka Rytty ${ }^{2,3}$, Virpi Moilanen ${ }^{4}$, \\ Ahmed Abou Elseoud ${ }^{2,5}$, Anne M Remes ${ }^{4,6,7,8}$, Vesa Kiviniemi ${ }^{1,2}$, ADNI^ \\ 1 Department of Diagnostic Radiology, Medical Research Center, \\ Oulu University Hospital, Oulu, Finland \\ 2 Oulu Functional NeuroImaging -group, Research unit of Medical Imaging, Physics \\ and Technology, University of Oulu, Oulu, Finland \\ 3 Department of Neurology, Hyvinkää Hospital, The Hospital District of Helsinki \\ and Uusimaa, Hyvinkää, Finland \\ 4 Department of Neurology, Medical Research Center Oulu, Oulu University \\ Hospital, Oulu, Finland \\ 5 Department of Radiology, Helsinki University Hospital, Helsinki, Finland \\ 6 Research Unit of Clinical Neuroscience, Faculty of Medicine, University of Oulu \\ 7 Institute of Clinical Medicine - Neurology, University of Eastern Finland, Kuopio, \\ Finland; \\ 8 Neurocenter, Neurology, Kuopio University Hospital, Kuopio, Finland \\ * Corresponding author \\ E-mail: timo.tuovinen@oulu.fi \\ ^ Alzheimer's disease neuroimaging initiative
}


Tuovinen et al.

\section{Abstract}

2 Recently discovered glymphatic brain clearance mechanisms utilizing physiological pulsations have

3 been shown to fail at removing waste materials such as amyloid and tau plaques in neurodegenerative

4 diseases. Since cardiovascular pulsations are a main driving force of the clearance, this research

5 investigates if commonly available blood oxygen level-dependent (BOLD) signals at 1.5 and $3 \mathrm{~T}$

6 could detect abnormal physiological pulsations in neurodegenerative diseases. Coefficient of variation

7 in BOLD signal $\left(\mathrm{CV}_{\mathrm{BOLD}}\right)$ was used to estimate contribution of physiological signals in Alzheimer's

8 disease (AD) and behavioural variant frontotemporal dementia (bvFTD). 17 AD patients and 18

9 bvFTD patients were compared to 24 control subjects imaged with a $1.5 \mathrm{~T}$ setup from a local institute.

$10 \mathrm{AD}$ results were further verified with $3 \mathrm{~T}$ data from the Alzheimer's disease neuroimaging initiative

11 (ADNI) repository with $30 \mathrm{AD}$ patients and 40 matched controls. Effect of motion and gray matter

12 atrophy was evaluated and receiver operating characteristic (ROC) analyses was performed.

13 The $\mathrm{CV}_{\mathrm{BOLD}}$ was higher in both $\mathrm{AD}$ and bvFTD groups compared to controls $(\mathrm{p}<0.0005)$. The

14 difference was not explained by head motion or gray matter atrophy. In $\mathrm{AD}$ patients, the $\mathrm{CV}_{\mathrm{BOLD}}$

15 alterations were localized in overlapping structures in both $1.5 \mathrm{~T}$ and $3 \mathrm{~T}$ data. Localization of the

$16 \mathrm{CV}_{\mathrm{BOLD}}$ alterations was different in $\mathrm{AD}$ than in bvFTD. Areas where $\mathrm{CV}_{\mathrm{BOLD}}$ is higher in patient

17 groups than in control group involved periventricular white matter, basal ganglia and multiple cortical

18 structures. Notably, a robust difference between $\mathrm{AD}$ and bvFTD groups was found in the $\mathrm{CV}_{\mathrm{BOLD}}$ of

19 frontal poles. In the analysis of diagnostic accuracy, the $\mathrm{CV}_{\mathrm{BOLD}}$ metrics area under the ROC for

20 detecting disease ranged $0.85-0.96$.

21 Conclusions: The analysis of brain physiological pulsations measured using $\mathrm{CV}_{\mathrm{BOLD}}$ reveals disease-

22 specific alterations in both $\mathrm{AD}$ and bvFTD. 
Tuovinen et al.

\section{Introduction}

The two most common forms of early-onset dementia are Alzheimer's disease (AD) and behavioral variant frontotemporal dementia (bvFTD). Multiple resting-state functional MRI (rs-fMRI) studies concerning $\mathrm{AD}$ and bvFTD have been published. In $\mathrm{AD}$ the findings have been relatively consistent, with reduced default mode network (DMN) connectivity reported in numerous studies, and it seems to correlate with disease severity [Agosta et al., 2012; Binnewijzend et al., 2012; Greicius et al., 2004; Hafkemeijer et al., 2012; Li et al., 2002; Zhou et al., 2010]. In bvFTD, reduced salience network (SLN) connectivity has been most reported finding, although there has been some diverseness [Farb et al., 2013; Filippi et al., 2013; Lee et al., 2014; Rytty et al., 2013; Zhou et al., 2010]. Advanced artifact removal affects the reproducibility of the functional connectivity findings [Griffanti et al., 2015; Tuovinen et al., 2017].

The blood oxygen level-dependent (BOLD) signal used in fMRI is an indirect marker of neuronal activity and also reflects other vascular, respiratory and physiological factors [Birn et al., 2006; Shmueli et al., 2007; Liu et al., 2013; Mark et al., 2015; Kiviniemi et al., 2016]. Brain activity induces a complex combination of changes in cerebral blood volume, cerebral blood flow, and oxygen extraction fraction that all affect the de-phasing of the water protons and modulate the $\mathrm{T} 2{ }^{*}$-weighted MRI signal intensity in the brain measured as BOLD signal [Buxton, 2012]. BOLD signal has marked correlation with cardiorespiratory pulsations due to the high sensitivity to blood flow status [Hoge et al., 1999; Wise et al., 2004; Birn et al., 2006; Chang et al., 2009; Chang and Glover, 2010; Birn et al., 2014]. Physiological fluctuations in BOLD signal have traditionally been considered as a nuisance concealing neural activity [Keilholz et al., 2017]

Physiological pulsations has been shown to be of vital importance for the homeostasis of the brain [Aspelund et al., 2015; Buxton, 2012; Buxton et al., 2014; Dreha-Kulaczewski et al., 2015; Erdő et al., 2017; Fleisher et al., 2009; Garrett et al., 2017; Glomb et al., 2018; Grady and Garrett, 2018; Iliff et al., 2013; Iliff et al., 2015; Martin et al., 2012; Nedergaard, 2013; Plog and Nedergaard, 2018]. The brain clearance driven by physiological pulsations has recently been strongly linked to neurodegenerative diseases [Iliff et al., 2012; Iliff et al., 2013; Iliff et al., 2014; Iliff et al., 2015; 
Tuovinen et al.

51 Kiviniemi et al., 2016; Kress et al., 2014; de Leon et al., 2017; Louveau et al., 2016; Peng et al., 2016;

52 Plog et al., 2015; Snyder et al., 2015; Tarasoff-Conway et al., 2015]. The disease process may also

53 alter the physiological noise structure or variability of the BOLD signal in the way it alters the low-

54 frequency connectivity. There may be yet unknown physiological factors that have been overlooked in

55 prior rs-fMRI data.

56 The temporal signal-to-noise ratio (tSNR) has been used to measure BOLD signal stability

57 [Triantafyllou et al., 2005]. The inverse of tSNR, i.e., the temporal coefficient of variation of the

58 BOLD signal $\left(\mathrm{CV}_{\mathrm{BOLD}}\right)$, is a similar quality assurance metric that also enables the detection of subtle

59 artifacts from the fMRI data [Tuovinen et al., 2017]. Recently, $\mathrm{CV}_{\mathrm{BOLD}}$ has been used to analyze

60 changes in noise characteristics of BOLD data [Jahanian et al., 2014]. Using a similar approach,

61 increased physiological fluctuations in white matter (WM) have been detected in AD [Makedonov et

62 al., 2016] and small vessel disease [Makedonov et al., 2013]. $\mathrm{CV}_{\text {BOLD }}$ correlates with cerebral blood

63 volume and cerebral blood flow measured using dynamic susceptibility contrast MRI in patients with

64 acute ischemic stroke [Khalil et al., 2017].

Based on previous findings of abnormal noise characteristics of the BOLD data, it was hypothesized that the noise structure of the BOLD signal measured using $\mathrm{CV}_{\mathrm{BOLD}}$ is altered in $\mathrm{AD}$ and bvFTD

67 patients in specific ways. AD and bvFTD patients as well as healthy controls were imaged with a $1.5 \mathrm{~T}$

68 setup from a local institute. Results of $\mathrm{AD}$ patients were further verified with $3 \mathrm{~T}$ data from the

69 Alzheimer's disease neuroimaging initiative (ADNI) repository. Effect of motion and atrophy was

70 evaluated.

\section{Materials and Methods}

Participants

73 The ethic committee of the Oulu University Hospital approved the study. Each participating site's

74 institutional review board approved the research protocols. Written informed consent was obtained

75 from all participants or their legal guardians according to the Declaration of Helsinki. 
Tuovinen et al.

\section{Local Institute Data}

The study sample consisted of $17 \mathrm{AD}$ patients, 18 bvFTD patients and 24 control subjects. The patients were examined at Oulu University Hospital at the Memory Outpatient Clinic of the Department of Neurology. They all underwent a thorough neurological and neuropsychological examination, screening laboratory tests and brain MRI that are routine in the clinic. All patients in the AD group met the NINCDS-ADRDA (National Institute of Neurological and Communicative Disorders and Stroke and the Alzheimer's Disease and Related Disorders Association) criteria for probable AD [McKhann et al., 1984]. Cerebrospinal fluid (CSF) AD biomarkers supported the diagnosis in all the cases with available results $(n=12)$.

The bvFTD patients were clinically diagnosed according to the Neary criteria [Neary et al., 1998; Rascovsky et al., 2011]. Patients with progressive aphasia or semantic dementia phenotypes were excluded from the study. DNA samples were available for ten patients, and the C9ORF72 repeat expansion was found in seven of them [Renton et al., 2011]. Mutations in progranulin or microtubuleassociated protein tau genes were not found in any of the genetically tested bvFTD patients.

The control subjects were interviewed, and Mini-Mental State Examination (MMSE) and Beck's Depression Inventory (BDI) were performed. No psychiatric or neurological disorders or medications affecting the central nervous system were allowed in the control group. Structural MRIs were interpreted as normal by clinical neuroradiologist.

The fMRI scan was performed within six months of the examination. The patients were allowed to continue their ongoing medications. Functional connectivity findings have been previously reported [Tuovinen et al., 2017]. These participants passed strict quality control prerequisites using methods published in that article.

\section{ADNI Data}

To verify the main results from local institute data a reference dataset was obtained for $\mathrm{AD}$ and control groups. Data used in the preparation of this article were obtained from the ADNI database (http://adni.loni.usc.edu). The ADNI was launched in 2003 as a public-private partnership, led by 
Tuovinen et al.

102 Principal Investigator, Michael W. Weiner, MD. The primary goal of ADNI has been to test whether

103 serial MRI, positron emission tomography (PET), other biological markers, and clinical and

104 neuropsychological assessment can be combined to measure the progression of mild cognitive impairment (MCI) and early AD. For up-to-date information, see http://www.adni-info.org.

ADNI-2 participants with both resting-state fMRI and preprocessed anatomical scans within the first year of participation in the study were selected to minimize potential retention bias from repeat scans. Participants were included if they were between 55 and 82 years old, spoke English or Spanish as their first language, and had completed at least six years of schooling. The diagnostic classification was made by ADNI investigators using established criteria [McKhann et al., 1984]. Participants in the AD cohort fulfilled the NINCDS-ADRDA criteria for probable AD. Control subjects had MMSE scores

112 between 24 and 30 and no significant memory concerns.

\section{Image Acquisition}

\section{Local Institute Data (1.5 T)}

115 The subjects were imaged with a GE Signa HDx $1.5 \mathrm{~T}$ whole-body system with an eight-channel

116 receiver coil. Subjects were given earplugs to reduce noise, and soft pads were fitted over the ears to 117 protect hearing and to minimize motion. During MRI scanning all the subjects received identical 118 instructions: to simply rest and focus on a cross on an fMRI-dedicated screen, which they saw through 119 the mirror system of the head coil.

120 Structural high-resolution T1-weighted 3D FSPGR BRAVO images were taken under the following 121 conditions: repetition time (TR) $12.1 \mathrm{~ms}$, echo time (TE) $5.2 \mathrm{~ms}$, flip angle (FA) of $20^{\circ}$, slice thickness $1221.0 \mathrm{~mm}$, field of view (FOV) $24.0 \mathrm{~cm}$, matrix size $256 \times 256$ (i.e., $1 \mathrm{~mm}^{3}$ cubic voxels).

123 Resting-state BOLD data were acquired using a conventional gradient recalled echo-planar images 124 (EPI) sequence under the following conditions: TR of $1800 \mathrm{~ms}$, TE of $40 \mathrm{~ms}, 202$ volumes (6 min $4 \mathrm{~s})$, 125 FA of $90^{\circ}, 28$ oblique axial slices, slice thickness $4 \mathrm{~mm}$, inter-slice space $0.4 \mathrm{~mm}$, covering the whole 126 brain, FOV $25.6 \mathrm{~cm}$ x $25.6 \mathrm{~cm}$, matrix size $64 \times 64$. The first three volumes were excluded from the 127 time series due to $\mathrm{T} 1$ relaxation effects. 
Tuovinen et al.

128

129

130

131

132

133

134

135

136

137

138

139

140

141

ADNI Data (3 T)

MRI images were collected on Philips 3 T MRI systems (Philips, Amsterdam, The Netherlands) from a total of 13 sites using a standardized protocol (http://adni.loni.usc.edu).

Structural T1 images were acquired with a TE of $3 \mathrm{~ms}$, TR of $7 \mathrm{~ms}$, FA of $9^{\circ}$, slice thickness of 1.2 $\mathrm{mm}$, and a matrix size of $256 \times 256 \times 170$. Preprocessing of the structural T1 images involved bias field correction using a histogram peak-sharpening algorithm (N3) [Sled et al., 1998] and was done already for the datasets downloaded.

Functional EPI images were acquired with a TR of 3,000 ms, TE of $30 \mathrm{~ms}, 140$ volumes ( $7 \mathrm{~min}$ ), FA of $80^{\circ}$, slice thickness of $3.3 \mathrm{~mm}$, and a matrix size of $64 \times 64 \times 48$. The first three volumes were excluded from the time series due to T1 relaxation effects.

\section{Data Preprocessing}

The BOLD rs-fMRI data were preprocessed with a typical FSL pipeline (http://www.fmrib.ox.ac.uk/fsl, FSL 5.0.8) including: head motion correction (FSL 5.0.8 MCFLIRT, motion estimates were also used in evaluating motion differences between groups), brain extraction (f $=0.5$ and $\mathrm{g}=0$ ), spatial smoothing (Gaussian kernel 5-mm full width at half maximum), and highpass temporal filtering by using a cutoff of 100 seconds. Multi-resolution affine co-registration within FSL FLIRT software was used to co-register mean, non-smoothed fMRI volumes to 3D FSGR volumes of corresponding subjects, and to co-register anatomical volumes to the Montreal Neurological Institute's (MNI152) standard space template.

\section{$C V_{B O L D}$ maps}

$\mathrm{CV}$ was used as a metric for the variation of fluctuations in the BOLD signal. The same method has been used in a study by [Jahanian et al., 2014] and is similar to the method used by [Makedonov et al., 2013; Makedonov et al., 2016].

For each preprocessed 4D fMRI dataset, a $\mathrm{CV}_{\text {BOLD }}$ map was calculated voxel-wise: 
Tuovinen et al.

$$
C V=\frac{\sigma(X)}{\mu(X)}
$$

where $\mathrm{X}$ is voxel time series, $\sigma$ is standard deviation and $\mu$ is mean.

154 Calculations were done using Matlab (version R2014b). Representative maps from one AD patient, 155 one bvFTD patient and one control subject, as well as the group mean $\mathrm{CV}_{\mathrm{BOLD}}$ maps, are shown in Fig.

1561 for both local institute and ADNI data.

Regions-of-Interest analysis based on anatomical templates

158 ICBM152 nonlinear asymmetric 2009c [Fonov et al., 2009; Fonov et al., 2011] atlases (probabilistic map, thresholded to 50-100\%) were used as gray matter (GM), WM and CSF templates for the regions-of-interest (ROI) analysis. This approach was used in a study by [Jahanian et al., 2014] where they also showed that results are somewhat independent of the precise GM, WM and CSF segmentation strategy employed. From these ROIs, mean $\mathrm{CV}_{\text {BOLD }}$ was calculated subject-wise.

164 Differences between study groups in the $\mathrm{CV}_{\mathrm{BOLD}}$ maps were statistically tested using permutationbased nonparametric testing incorporating threshold-free cluster enhancement (TFCE) implemented in the FSL randomise tool with 10,000 random permutations [Smith and Nichols, 2009]. Resulting statistical maps were thresholded at $\mathrm{p}<0.05,0.005$ and 0.0005 . The effect of GM atrophy on the $\mathrm{CV}_{\mathrm{BOLD}}$ maps was also evaluated repeating the randomize analysis using the $\mathrm{GM}$ volume as a regressor. The resulting statistic maps were spatially correlated to the ones without a GM regressor using the fslcc tool from FSL.

172 Motion estimates computed by the MCFLIRT algorithm in the preprocessing step was used to assess 173 the effect of motion on the $\mathrm{CV}_{\mathrm{BOLD}}$ values. Subject-wise absolute displacement vectors (in $\mathrm{mm}$ ) were extracted, which describes the amount of movement in all directions over the whole scan as a marker of gross motion. Also, relative displacement vectors were extracted, as a marker of motion between each EPI volume. Both vectors were also averaged across volumes to get mean values. Additionally, 
Tuovinen et al.

177 maximum motion value and the number of peaks in the subject-wise motion data were calculated

178 using max and findpeak functions implemented in Matlab R2014b.

179 A univariate linear model analysis of covariance (ANCOVA) was conducted to determine a 180 statistically significant difference between different study groups on the mean $\mathrm{CV}_{\mathrm{BOLD}}$ values in 181 different ROIs (GM, WM and CSF) controlling for motion parameters. This was performed by using 182 SPSS for Windows statistical software (version 24.0; SPSS, Chicago, Illinois).

183 Furthermore, the effect of removal of residual motion was assessed using the additional preprocessing 184 step of spike removal from the time-series with the AFNI 3dDespike tool using default threshold 185 settings. After $3 \mathrm{dDespike,} \mathrm{the} \mathrm{CV}_{\mathrm{BOLD}}$ maps were calculated and tissue-template-based mean $\mathrm{CV}_{\mathrm{BOLD}}$ 186 values were compared to the ones calculated without despiking. Effect of gray matter atrophy

Structural data were analyzed with FSL-VBM, a voxel-based morphometry-style analysis [Ashburner and Friston, 2000; Good et al., 2001]. Structural images were brain-extracted using BET [Smith,

190 2002]. This procedure was verified with visual inspection of the extraction results. Tissue-type 191 segmentation into GM, WM and CSF was carried out using FAST4 (55). The resulting GM partial 192 volume images were then aligned to the Montreal Neurological Institute's (MNI152) standard 193 structural space template using the affine registration tool FLIRT [Jenkinson et al., 2002; Jenkinson 194 and Smith, 2001], followed optionally by nonlinear registration using FNIRT 195 (www.fmrib.ox.ac.uk/analysis/techrep), which uses a b-spline representation of the registration warp 196 field [Rueckert et al., 1999].

197 To analyze the between-group differences on GM atrophy patterns, these resulting images were averaged to create a study-specific template, to which the native GM images were then nonlinearly re-

199 registered. The registered partial volume images were then modulated to correct for local expansion or 200 contraction by dividing by the Jacobian of the warp field. The modulated segmented images were then 201 smoothed with an isotropic Gaussian kernel with a sigma of $4 \mathrm{~mm}$. Finally, GM differences between 202 different study groups were statistically tested using permutation-based nonparametric testing 
Tuovinen et al.

incorporating TFCE implemented in the FSL randomise tool with 10,000 random permutations [Smith

204 and Nichols, 2009]. Resulting statistical maps were thresholded at $\mathrm{p}<0.05$ (TFCE-corrected for

205 familywise errors).

206 To analyze the effect of $\mathrm{GM}$ atrophy on $\mathrm{CV}_{\mathrm{BOLD}}$ values $\mathrm{GM}$ volume in voxels was correlated

207 subjectwise with mean $\mathrm{CV}_{\text {BOLD }}$ values (within GM, WM and CSF) using Spearman's rank correlation

208 coefficient. Scatter plots were used to visualize the results. The effect of GM atrophy was also

209 evaluated repeating the FSL randomise analysis but using this time the GM volume as a regressor. The

210 resulting statistic maps were spatially correlated to the ones without GM regressor using fslcc tool

211 from FSL.

212 Receiver operating characteristic curves

213 We plotted receiver operating characteristic (ROC) curves to evaluate whether $\mathrm{CV}_{\text {BOLD }}$ could be used

214 to separate healthy controls from patients with either AD or bvFTD, or patient groups from each other.

215 The mean $\mathrm{CV}_{\text {BOLD }}$ was calculated using different ROIs: GM, WM, CSF (Fig. 2) and disease-specific

216 templates (Fig. 3A). Area under the curve (AUC) was calculated as a measure of classification

217 accuracy. The bootstrap approach was used to estimate the 95\% confidence interval of AUC in SPSS

$218 \quad$ v24.

219 Statistical Analysis

220 Statistical analyses were performed with the SPSS and Matlab software, and p values of less than 0.05

221 were considered to indicate a significant difference for all analyses. Between-group differences were

222 assessed using Kruskal-Wallis, two-tailed $t$ and $X^{2}$ tests, as appropriate. Subject-wise mean motion

223 and $\mathrm{GM}$ volume values were correlated with the mean $\mathrm{CV}_{\mathrm{BOLD}}$ values using Spearman's rank

224 correlation coefficient. 
Tuovinen et al.

225

226

227

228

230

231

232

\section{Results}

\section{Characteristics of Participants}

A total of 64 healthy controls, 47 AD and 18 bvFTD patients were eligible for analysis. Demographics and clinical data are summarized in Table 1 for the local institute and in Table 2 for the ADNI data.

\section{$C V_{B O L D}$ is elevated in both $A D$ and $b v F T D$}

Both $\mathrm{AD}$ and bvFTD patients showed higher $\mathrm{CV}_{\mathrm{BOLD}}$ values than the controls based on visual inspection of the $\mathrm{CV}_{\mathrm{BOLD}}$ maps. The group mean and examples of single-subject $\mathrm{CV}_{\mathrm{BOLD}}$ maps are shown in Fig. 1.

To analyze this further, template-based ROI-analysis was conducted using ICBM152 tissue-template for WM, GM and CSF (Fig. 2). The $\mathrm{CV}_{\mathrm{BOLD}}$ values on average were higher in both patient groups than in the control group (p-values ranging from 0.008 to 0.00001 ). This difference was confirmed using data from the $\mathrm{ADNI}$ study. The lowest $\mathrm{CV}_{\mathrm{BOLD}}$ values were detected in the $\mathrm{WM}$ in all of the study groups. In the bvFTD group, mean $\mathrm{CV}_{\mathrm{BOLD}}$ values were higher in $\mathrm{WM}$ and $\mathrm{GM}$ compared to both $\mathrm{AD}$ and the control group (Fig. 2). In the $\mathrm{AD}$ group, the mean $\mathrm{CV}_{\mathrm{BOLD}}$ values were higher in the CSF compared to bvFTD and control group. However, the difference between bvFTD and AD groups in the large-scale ROI-analysis did not reach statistical significance $(\mathrm{p}=0.27)$.

\section{The $C V_{B O L D}$ demonstrates disease-specific changes}

More-detailed voxel-level differences of $\mathrm{CV}_{\mathrm{BOLD}}$ values between study groups were analyzed using permutation-based nonparametric testing incorporating TFCE with 10,000 random permutations. This revealed distinct differences between the patient and control groups. In the AD group, significantly higher $\mathrm{CV}_{\mathrm{BOLD}}$ values compared to control group were located closer to the center in periventricular $\mathrm{WM}$; in GM higher $\mathrm{CV}_{\mathrm{BOLD}}$ values are located in the parietal, occipital and posterior part of frontal lobes as well as in frontal pole. In the bvFTD group differences extend more to external parts of the WM and towards the frontal and temporal lobes as well as the middle occipital gyri. There are also higher $\mathrm{CV}_{\mathrm{BOLD}}$ values in the cerebellum near the 4 th ventricle in both diseases. In $\mathrm{AD}$ higher $\mathrm{CV}_{\mathrm{BOLD}}$ 
Tuovinen et al.

250 values located more towards the horizontal fissure in posterior lobe. In order to pinpoint the most

251 significant changes, the most statistically significant differences are illustrated with $\mathrm{p}<0.005$ and $\mathrm{p}<$

2520.0005 in Fig. 3 and in supplementary Fig. S1.

253 Statistically significant $(\mathrm{p}<0.005)$ voxel-wise differences between AD patients and controls showed 254 increased $\mathrm{CV}_{\mathrm{BOLD}}$ accumulated in a circular area around the CSF ventricles centered on WM. The 255 increased $\mathrm{CV}_{\text {BOLD }}$ values are found symmetrically in corpus callosum, thalamus, putamen, sagittal 256 stratum, insula and also amygdala and anterior hippocampi areas as well as cerebellum. In the GM 257 increased $\mathrm{CV}_{\mathrm{BOLD}}$ are found in Broca's areas, somatosensory, supplementary and sensorimotor SM1 258 cortices, paracingulate gyri, and also in visual V1-V3 cortices. Notably, there was no statistically 259 significant difference between $\mathrm{AD}$ and control group in the parts of the DMN (posterior cingulate, 260 angular and medial prefrontal gyri). The spatial localizations of the statistically significant changes in $261 \mathrm{CV}_{\mathrm{BOLD}}$ values were markedly similar to the results of the ADNI data (Fig. 4).

262 The most prominent changes in bvFTD patients showed increased $\mathrm{CV}_{\mathrm{BOLD}}$ values more towards the 263 frontal areas and lateral periventricular structures, and towards the temporal pole, premotor cortex and 264 temporal fusiform cortex, and also in visual areas V3-V5 in lateral occipital cortex. Bilateral 265 amygdala, putamen, insula, hippocampus, and areas in the cerebellum showed also higher $\mathrm{CV}_{\mathrm{BOLD}}$ 266 values (Fig. 3).

267 The statistically significant differences between the AD and bvFTD (bvFTD>AD) patients on voxel268 level $\mathrm{CV}_{\mathrm{BOLD}}$ were located bilaterally in anterior part of the frontal lobe (Fig. 3C).

269 The supplementary Tables S1-3 show the most significant group difference clusters and their 270 anatomical labeling in the local institute data.

272 There were no significant differences in the absolute or relative head motion parameters between any 273 of the study groups in the local institute data (Fig. 5). In the ADNI dataset, the AD patients moved more before the motion correction (absolute: $0.20 \mathrm{~mm}$ for the control group and $0.30 \mathrm{~mm}$ for the $\mathrm{AD}$ 
Tuovinen et al.

275 group, $\mathrm{p}=0.03$; relative: control $0.15 \mathrm{~mm}$ and $\mathrm{AD} 0.21 \mathrm{~mm}, \mathrm{p}=0.02)$. Head motion did not exceed half 276 a voxel size.

277 Mean $\mathrm{CV}_{\mathrm{BOLD}}$ values did correlate to motion (Fig. 5A, correlation coefficient $\mathrm{R}$ ranging from 0.22 to 278 0.50). However, there is still a highly statistically significant effect of study group on the mean $279 \mathrm{CV}_{\mathrm{BOLD}}$ values after controlling for motion parameters, c.f. Table 3 (ANCOVA).

280 The number of peaks in the motion signal was also analyzed as markers of sudden head movement. No 281 statistically significant differences were found between groups and there was no correlation to the $282 \mathrm{CV}_{\text {BOLD }}$ values (data not shown, $\mathrm{R}$ ranging from -0.12 to $0.22, \mathrm{p}>0.05$ [0.17 to 0.45$]$ ).

283 We further verified the effects of motion by performing scrubbing of residual motion spikes (AFNI $2843 \mathrm{dDespike)}$ ) and repeated the analysis of $\mathrm{CV}_{\mathrm{BOLD}}$ group differences. The results were not affected by 285 despiking, and there was no significant difference between mean $\mathrm{CV}_{\mathrm{BOLD}}$ values calculated before and 286 after 3dDespike ( $>0.05[0.68-0.98])$.

287 The effect of GM atrophy on $\mathrm{CV}_{\text {BOLD }}$ values was analyzed using the local institute dataset (Fig. 6).

288 There was no correlation between the mean $\mathrm{CV}_{\mathrm{BOLD}}$ values and volume of $\mathrm{GM}(\mathrm{R}=-0.01, \mathrm{p}=0.91)$. The 289 use of GM maps as a regressor in voxel-level analysis implementing FSL randomise resulted statistical 290 maps that were $99 \%$ the same as those without a regressor (spatial correlation coefficient $\mathrm{R}=0.99$ ).

The accuracy of separating controls from patients with $C V_{B O L D}$

292 The mean $\mathrm{CV}_{\mathrm{BOLD}}$ calculated from the disease-specific templates showed excellent diagnostic 293 accuracy. Both AD and bvFTD can be differentiated from the controls in local data with 0.96 ROC 294 AUC values. The method also enables differentiation between AD and bvFTD, AUC being 0.806 (Fig. 295 7, Table 4).

\section{Discussion}

297 The goal of this study was to investigate if physiological signal contributions of BOLD data measured 298 using $\mathrm{CV}_{\mathrm{BOLD}}$ are altered in different types of dementia. We found that $\mathrm{CV}_{\mathrm{BOLD}}$ is markedly increased 299 in both $\mathrm{AD}$ and bvFTD compared to age-matched controls $(\mathrm{p}<0.0005)$, and that the $\mathrm{CV}_{\mathrm{BOLD}}$ changes 
Tuovinen et al.

300 are motion and GM atrophy independent and therefore presumably intrinsic physiological changes.

301 Localizations of the $\mathrm{CV}_{\text {BOLD }}$ alterations are somewhat disease-specific. However in both diseases, the

302 most profound changes in the $\mathrm{CV}_{\mathrm{BOLD}}$ involve areas surrounding CSF, extending to $\mathrm{WM}$, basal ganglia

303 and multiple cortical structures. Suiting the disease pathology of the bvFTD, the most significant

304 differences in $\mathrm{CV}_{\mathrm{BOLD}}$ comparison to $\mathrm{AD}$ were detected in frontolateral $\mathrm{GM}$ areas. $\mathrm{Mean} \mathrm{CV}_{\mathrm{BOLD}}$ in

305 the disease-specific templates was able to discern $\mathrm{AD}$ patients from controls with the receiver

306 operating characteristic AUC values of 0.963 and bvFTD patients from controls with an AUC value of

307 0.958. The AD and bvFTD groups were separated from each other with an AUC value of 0.806.

308 Garrett et al. has suggested that it would be beneficial to broaden the analysis of BOLD signal to

309 variability, as it seems to be more than just noise [Garrett et al., 2010]. BOLD signal variability has

310 been measured with standard deviation of BOLD signal $\left(\mathrm{SD}_{\mathrm{BOLD}}\right)$ [McIntosh et al., 2010; Wang et al.,

311 2008]. $\mathrm{SD}_{\mathrm{BOLD}}$ has been found to reflect brain status, and that is also related to aging, pathology,

312 cognitive skills and AD [Garrett et al., 2010; Garrett et al., 2011; Garrett et al., 2013; Garrett et al.,

313 2015; Grady and Garrett, 2014; Grady and Garrett, 2018; Guitart-Masip et al., 2016; Scarapicchia et

314 al., 2018]. Recently, $\mathrm{CV}_{\mathrm{BOLD}}$ has been used to analyze physiological noise characteristics of BOLD

315 data [Jahanian et al., 2014]. $\mathrm{CV}_{\mathrm{BOLD}}$ has been shown to correlate with cerebral blood volume and

316 cerebral blood flow [Khalil et al., 2017]. The theoretical advantage of $\mathrm{CV}_{\text {bold }}$ over $\mathrm{SD}_{\text {bold }}$ is that any

317 intensity level changes are normalized to the average BOLD signal level of the voxel minimizing the

318 effects of local things like susceptibility alterations. While BOLD signal has conventionally been

319 related to GM, recent studies have shown increasing evidence of WM contribution to BOLD signal, as

320 well as that there are disease-related changes in it [Ding et al., 2018; Gawryluk et al., 2014; Özbay et

321 al., 2018; Peer et al., 2017]. Using a similar approach as $\mathrm{CV}_{\text {BOLD }}$ Makedonov et al. has shown

322 increased physiological fluctuations in WM in AD [Makedonov et al., 2016] and in small vessel

323 disease [Makedonov et al., 2013]. Makedonov et al. has suggested that the BOLD signal variation

324 reflects end-arteriole intracranial pulsatility effects [Makedonov et al., 2013].

$325 \mathrm{AD}$ is usually been considered as a GM disease due to the distribution of hallmark pathological 326 changes such as abnormal extracellular aggregates of amyloid-beta $(A \beta)$ protein and intracellular 
Tuovinen et al.

327 neurofibrillary tangles of hyperphosphorylated tau protein [Selkoe, 1991; Ryan et al., 2015]. However,

328 the pathogenesis of $\mathrm{AD}$ is still controversial. $\mathrm{AD}$ is also linked to loss of synapsis and myelin,

329 mitochondrial dysfunction, oxidative stress, metabolic disorders, neuroinflammation and loss of

330 cholinergic and other neurons [Holtzman et al., 2011; Audano et al., 2018; Bartzokis, 2011; Mark et

331 al., 2015; Olsson et al., 2016; Tracy and Gan, 2018; Wang et al., 2016]. Patients with clinically

332 diagnosed $\mathrm{AD}$ have commonly mixed $\mathrm{AD}$ and cerebrovascular disease pathology, and there has been

333 much interest in the interactions between these diseases [Toledo et al., 2013]. The cardiovascular and

334 respiratory pulsations drive the glymphatic clearance of the brain. Glymphatic failure has been

335 strongly linked to neurodegenerative diseases [Iliff et al., 2012; Iliff et al., 2013; Iliff et al., 2014; Iliff

336 et al., 2015; Kiviniemi et al., 2016; Kress et al., 2014; de Leon et al., 2017; Louveau et al., 2016; Peng

337 et al., 2016; Plog et al., 2015; Snyder et al., 2015; Tarasoff-Conway et al., 2015]. B-amyloid has been

338 found to increase in the periventricular WM already after one night sleep deprivation, which suggests

339 that absence of nighttime glymphatic brain clearance surge may predispose to amyloid deposition and

340 neuronal degeneration [Shokri-Kojori et al., 2018; Xie et al., 2013].

341 Cerebral small vessel disease is increasingly linked to cognitive decline and dementia [Bos et al.,

342 2018]. On T2-weighted MRI, white matter disease (WMD) is represented as white matter

343 hyperintensities (WMH), which are thought to reflect demyelination and axonal loss. WMH is a good

344 predictor of $\mathrm{AD}$ incidence and early $\mathrm{AD}$ patients with micro- and macro-structural abnormalities in the

345 white matter have higher risk of disease progression [Brickman et al., 2012; Brickman, 2013;

346 Brickman et al., 2015; Sjöbeck et al., 2006; Tosto et al., 2014]. Magnetic susceptibility differences has

347 been associated with tau pathology and increased staining for reactive microglia and astrocytes

348 [Acosta-Cabronero et al., 2013; O'Callaghan et al., 2017].

349 In the present study, analysis of $\mathrm{CV}_{\text {BOLD }}$ was not limited to $\mathrm{WM}$ as in previous study by [Makedonov

350 et al., 2016]. However, $\mathrm{CV}_{\mathrm{BOLD}}$ was altered in $\mathrm{AD}$ most dominantly in the periventricular WM

351 structures like corpus callosum. A decrease of vessel density in the periventricular region has been

352 observed in AD [Brown et al., 2009]. Demyelinated lesions tend to distribute within the areas with

353 relatively low cerebral blood flow, which are usually found in profound, periventricular WM. Our 
Tuovinen et al.

354 results add further proof into the vascular abnormalities by showing changes in $\mathrm{CV}_{\mathrm{BOLD}}$ within the 355 WM.

356 We also analyzed $\mathrm{CV}_{\mathrm{BOLD}}$ in different type of dementia (bvFTD). The neuropathology associated with 357 bvFTD is heterogeneous, and at the moment there is no clear relationship between the clinical 358 phenotype and the underlying pathogenesis. One of the most consistent pathological finding of bvFTD 359 is the relatively selective atrophy of the frontal and temporal lobes. In most cases post-mortem 360 immunohistopathology shows abnormal protein inclusions in neural and glial cells. Based on 361 immunohistochemical staining there are multiple subtypes of bvFTD (major subtypes being tau and 362 TDP) [Mackenzie et al., 2010]. bvFTD has been found to be associated with progressive degeneration 363 of the SLN resting-state network [Lee et al., 2014; Seeley et al., 2009; Seeley et al., 2012]. SLN is a 364 resting-state network that includes the anterior cingulate and frontoinsular cortex, amygdala, striatum, 365 and medial thalamus. These region bridges the frontal lobes and limbic system, and it has been 366 proposed to represent the emotional significance of internal and external stimuli and coordinate 367 contextualized viscero-autonomic, cognitive, and behavioural responses [Lee et al., 2014; Seeley et al., 368 2007; Whitwell and Josephs, 2012]. The other resting-state networks have received much less interest, 369 and there have been more controversies between results [Farb et al., 2013; Filippi et al., 2013; 370 Hafkemeijer et al., 2012; Rytty et al., 2013; Tuovinen et al., 2017].

371 In areas that are part of the $\mathrm{SLN}, \mathrm{CV}_{\mathrm{BOLD}}$ is higher in bvFTD, compared to control group. Interestingly, 372 the regions of the $\mathrm{DMN}$ were not found to have higher $\mathrm{CV}_{\mathrm{BOLD}}$ values in the $\mathrm{AD}$ group. Recent study 373 showed that bvFTD patients displayed more fixations to the eyes of the emotional faces, compared to 374 controls [Hutchings et al., 2018]. Regions associated with fixations to the eyes included the left 375 inferior frontal gyrus, right cerebellum and middle temporal gyrus; in this study these areas were 376 found to have higher $\mathrm{CV}_{\text {BOLD }}$ values. Both of the diseases seem to affect the $\mathrm{CV}_{\mathrm{BOLD}}$ measured from 377 the cerebellum. Cerebellar atrophy have been found in both AD and bvFTD [Gellersen et al., 2017].

378 In the present study the significant difference between the AD and bvFTD was shown to be in bilateral 379 frontal poles. The known neuropsychological differences between AD and bvFTD can be in part 380 explained by the $\mathrm{CV}_{\mathrm{BOLD}}$ differences between the conditions in the frontopolar areas. These areas are 
Tuovinen et al.

381 known have a role in resolving indeterminate relations in un-certain situations and intensity of

382 emotions [Goel et al., 2009]. Left ventral prefrontal cortex is involved in active and strategic operation

383 of the mnemonic representation and retrieval success for words [Iidaka et al., 2000]. Study by Wong et

384 al. contrasted prefrontal cortex atrophy with episodic memory dysfunction in AD and bvFTD [Wong

385 et al., 2014]. Episodic memory deficits are underpinned by divergent prefrontal mechanisms: left side

386 frontal pole for $\mathrm{AD}$ and right side for bvFTD, similar to our results. Our results indicate that the most

387 marked alterations in bvFTD occur in the right lateral areas of frontal poles with increased $\mathrm{CV}_{\mathrm{BOLD}} \mathrm{A}$

388 study comparing AD and bvFTD revealed non-atrophy related perfusion deficits in frontal areas in

389 accordance with our results [Du et al., 2006].

390 When compared to bvFTD, $\mathrm{CV}_{\mathrm{BOLD}}$ changes in $\mathrm{AD}$ occur more on the basal, periventricular areas

391 where cardiovascular pulsations dominate in physiological studies [Kiviniemi et al., 2016]. The

392 bvFTD changes are occurring more towards the frontal cortical edges of the brain, which was recently

393 shown to be connected to respiratory brain pulsations of the glymphatic system [Kiviniemi et al.,

394 2016]. Interestingly, arterial hypertension and other vascular risk factors are known risk factors for

395 AD, but not for bvFTD [Baborie et al., 2011; Baborie et al., 2012; De Reuck, 2012; De Reuck et al.,

396 2012a; De Reuck et al., 2012b; Snyder et al., 2015].

397 The changes in $\mathrm{CV}_{\mathrm{BOLD}}$ in present study are not explained by difference in age, gender, motion or GM

398 atrophy. There were no statistically significant differences in age, gender or motion parameters

399 between different study groups in the local institute data. As expected, there was a positive correlation

400 with $\mathrm{CV}_{\mathrm{BOLD}}$ values and motion parameters in all groups alike. However, the patient groups had

401 increased $\mathrm{CV}_{\mathrm{BOLD}}$ values with the same amount of motion. The effect of motion was also evaluated

402 using an ANCOVA, where differences between groups prevailed as statistically significant after

403 motion parameters were used as covariates. Also, the effect of sudden motion "peaks" was evaluated

404 and this did not explain the group differences in the $\mathrm{CV}_{\mathrm{BOLD}}$ values. Furthermore, removal of residual

405 motion spikes by despiking had no significant effect on the $\mathrm{CV}_{\text {BOLD }}$ results. GM atrophy patterns were

406 in line with previous literature [Du et al., 2006; Hartikainen et al., 2012; Tartaglia et al., 2011; 
Tuovinen et al.

407 Whitwell and Josephs, 2012]. $\mathrm{CV}_{\text {BOLD }}$ values and GM volume had no correlation. The use of GM

408 maps, as a regressor in voxel-level analysis did not affect the results.

409 The previous literature and our results suggest that the changes in $\mathrm{CV}_{\mathrm{BOLD}}$ are not only due to motion,

410 but rather the changes may be due to yet unknown intrinsic properties of the degenerated brain tissue.

411 ADNI data may be more sensitive to hemodynamically coupled BOLD signal changes due to the

412 higher magnetic field strength (3 T) than in local institute data (1.5 T) [van der Zwaag et al., 2009].

413 However, the increased motion in ADNI data may partly mask the $\mathrm{CV}_{\mathrm{BOLD}}$ differences between

414 groups. Furthermore, the local institute data is also nearly two times faster in sampling rate (TR 1.8 vs.

4153 seconds). This may partially increase the sensitivity to physiological pulsation noise due to

416 somewhat reduced aliasing with faster TR [Kiviniemi et al., 2005; Smith et al., 2007]. Furthermore, as

417 the differences predominate in CSF and WM structures, the source of T2*-weighted GRE EPI signal's

$418 \mathrm{CV}_{\mathrm{BOLD}}$ alterations in $\mathrm{AD}$ and bvFTD are most likely due to physiological brain pulsations rather than

419 secondary hemodynamic changes to neuronal activity. Both local institute and ADNI data still suffer

420 from cardiorespiratory signal aliasing and cannot pinpoint the physiological origin of the changes in

$421 \mathrm{CV}_{\mathrm{BOLD}}$. In future studies, one could investigate the source of altered $\mathrm{CV}_{\mathrm{BOLD}}$ in neurodegenerative

422 diseases with ultra-fast, critically sampled multimodal neuroimaging data. Such data can differentiate

423 cardiorespiratory pulsations and bring forth a mechanistic explanation to the detected alteration in

$424 \mathrm{CV}_{\text {BOLD. }}$

These results should be verified with larger sample sizes and the relationship between $\mathrm{CV}_{\mathrm{BOLD}}$ and clinical parameters, including precise co-analysis of structural images, should be evaluated. Previous studies have employed a number of different variations of 'BOLD variability' measures, with different methodologies used by different groups. There have not been comparative studies of different methodologies in this field. However, these results are inline with previous literature and together with

430 previous studies, our findings suggest that analysis of physiological pulsations using BOLD signal 431 variability may provide useful information in the context of neurodegenerative diseases. 

aCC-BY 4.0 International license.

Tuovinen et al.

\section{Conclusions}

434 There are disease specific alterations in $\mathrm{CV}_{\mathrm{BOLD}}$. In $\mathrm{AD}$ these alterations was confirmed in two 435 different datasets and in different imaging setups (1.5 $\mathrm{T}$ and $3 \mathrm{~T}) \cdot \mathrm{CV}_{\mathrm{BOLD}}$ changes are motion and $\mathrm{GM}$ atrophy independent and therefore presumably intrinsic physiological changes. Together with previous

437 studies, our findings suggest that analysis of physiological pulsations may provide useful information 438 in the context of neurodegenerative diseases.

\section{Acknowledgements}

441 Data collection and sharing for this project was funded by the Alzheimer's Disease Neuroimaging Initiative (ADNI) (National Institutes of Health Grant U01 AG024904) and DOD ADNI (Department of Defense award number W81XWH-12-2-0012). ADNI is funded by the National Institute on Aging, the National Institute of Biomedical Imaging and Bioengineering, and through generous contributions from the following: AbbVie, Alzheimer's Association; Alzheimer's Drug Discovery Foundation; Araclon Biotech; BioClinica, Inc.; Biogen; Bristol-Myers Squibb Company; CereSpir, Inc.; Cogstate; (www.fnih.org). The grantee organization is the Northern California Institute for Research and Education, and the study is coordinated by the Alzheimer's Therapeutic Research Institute at the 
bioRxiv preprint doi: https://doi.org/101101/455683; this version posted October 29, 2018. The copyright holder for this preprint (which was not certified by peer review) is the author/funder, who has granted bioRxiv a license to display the preprint in perpetuity. It is made available under aCC-BY 4.0 International license.

Tuovinen et al.

\section{$460 \quad$ Funding}

461 This work was supported by grants from Academy of Finland grants 117111 and 123772 (VK),

462 Finnish Medical Foundation (VK, AMR, TT), Finnish Neurological Foundation, JAES-Foundation

463 (VK), KEVO grants from Oulu University hospital (VK, AMR), National Graduate School of Clinical

464 Investigation (RR), Finnish Brain Foundation (RR), Epilepsy Research Foundation (JK), Finnish

465 Cultural Foundation, North Ostrobothnia Regional Fund (JK), Orion Research Foundation (TT, JK),

466 Tauno Tönning Foundation (JK)

467 
Tuovinen et al.

468

469

470

471

472

473

474

475

476

\section{References}

Acosta-Cabronero J, Williams GB, Cardenas-Blanco A, Arnold RJ, Lupson V, Nestor PJ (2013): In Vivo Quantitative Susceptibility Mapping (QSM) in Alzheimer's Disease. Ed. James R. Connor. PLoS ONE 8:e81093.

Agosta F, Pievani M, Geroldi C, Copetti M, Frisoni GB, Filippi M (2012): Resting state fMRI in Alzheimer's disease: beyond the default mode network. Neurobiology of Aging 33:15641578

Ashburner J, Friston KJ (2000): Voxel-Based Morphometry-The Methods. NeuroImage 11:805-821.

Aspelund A, Antila S, Proulx ST, Karlsen TV, Karaman S, Detmar M, Wiig H, Alitalo K (2015): A dural lymphatic vascular system that drains brain interstitial fluid and macromolecules. The Journal of Experimental Medicine 212:991-999.

Audano M, Schneider A, Mitro N (2018): Mitochondria, lysosomes and dysfunction: their meaning in neurodegeneration. Journal of Neurochemistry. http://doi.wiley.com/10.1111/jnc.14471.

Baborie A, Griffiths TD, Jaros E, Momeni P, McKeith IG, Burn DJ, Keir G, Larner AJ, Mann DM, Perry R (2012): Frontotemporal dementia in elderly individuals. Arch Neurol 69:10521060.

Baborie A, Griffiths TD, Jaros E, McKeith IG, Burn DJ, Richardson A, Ferrari R, Moreno J, Momeni P, Duplessis D, Pal P, Rollinson S, Pickering-Brown S, Thompson JC, Neary D, Snowden JS, Perry R, Mann DMA (2011): Pathological correlates of frontotemporal lobar degeneration in the elderly. Acta Neuropathologica 121:365-371.

Bartzokis G (2011): Alzheimer's disease as homeostatic responses to age-related myelin 
Tuovinen et al.

breakdown. Neurobiology of Aging 32:1341-1371.

492 Binnewijzend MAA, Schoonheim MM, Sanz-Arigita E, Wink AM, van der Flier WM,

493 Tolboom N, Adriaanse SM, Damoiseaux JS, Scheltens P, van Berckel BNM, Barkhof F

494 (2012): Resting-state fMRI changes in Alzheimer's disease and mild cognitive impairment.

495 Neurobiology of Aging 33:2018-2028.

496 Birn RM, Cornejo MD, Molloy EK, Patriat R, Meier TB, Kirk GR, Nair VA, Meyerand ME,

497 Prabhakaran V (2014): The influence of physiological noise correction on test-retest

498 reliability of resting-state functional connectivity. Brain Connect 4:511-522.

499 Birn RM, Diamond JB, Smith MA, Bandettini PA (2006): Separating respiratory-variation-

500 related fluctuations from neuronal-activity-related fluctuations in fMRI. Neuroimage

$501 \quad 31: 1536-1548$.

502 Bos D, Wolters FJ, Darweesh SKL, Vernooij MW, de Wolf F, Ikram MA, Hofman A (2018):

503 Cerebral small vessel disease and the risk of dementia: A systematic review and meta-analysis

504 of population-based evidence. Alzheimer's \& Dementia.

505 https://linkinghub.elsevier.com/retrieve/pii/S1552526018301298.

506 Brickman AM (2013): Contemplating Alzheimer's disease and the contribution of white

507 matter hyperintensities. Curr Neurol Neurosci Rep 13:415.

508 Brickman AM, Provenzano FA, Muraskin J, Manly JJ, Blum S, Apa Z, Stern Y, Brown TR,

509 Luchsinger JA, Mayeux R (2012): Regional white matter hyperintensity volume, not

510 hippocampal atrophy, predicts incident Alzheimer disease in the community. Arch Neurol

$511 \quad 69: 1621-1627$.

512 Brickman AM, Zahodne LB, Guzman VA, Narkhede A, Meier IB, Griffith EY, Provenzano

513 FA, Schupf N, Manly JJ, Stern Y, Luchsinger JA, Mayeux R (2015): Reconsidering 
Tuovinen et al.

514 harbingers of dementia: progression of parietal lobe white matter hyperintensities predicts

515 Alzheimer's disease incidence. Neurobiol Aging 36:27-32.

516 Brown WR, Moody DM, Thore CR, Anstrom JA, Challa VR (2009): Microvascular changes

517 in the white mater in dementia. Journal of the Neurological Sciences 283:28-31.

518 Brun A, Englund E (1986): A white matter disorder in dementia of the Alzheimer type: a

519 pathoanatomical study. Ann Neurol 19:253-262.

520 Buxton RB (2012): Dynamic models of BOLD contrast. Neuroimage 62:953-961.

521 Buxton RB, Griffeth VEM, Simon AB, Moradi F (2014): Variability of the coupling of blood

522 flow and oxygen metabolism responses in the brain: a problem for interpreting BOLD studies

523 but potentially a new window on the underlying neural activity. Frontiers in Neuroscience 8.

524 http://journal.frontiersin.org/article/10.3389/fnins.2014.00139/abstract.

525 Chang C, Cunningham JP, Glover GH (2009): Influence of heart rate on the BOLD signal: the 526 cardiac response function. Neuroimage 44:857-869.

527 Chang C, Glover GH (2010): Time-frequency dynamics of resting-state brain connectivity 528 measured with fMRI. NeuroImage 50:81-98.

De Reuck J, Deramecourt V, Cordonnier C, Auger F, Durieux N, Bordet R, Maurage CA, 530 Leys D, Pasquier F (2012a): Detection of microbleeds in post-mortem brains of patients with 531 frontotemporal lobar degeneration: a 7.0-Tesla magnetic resonance imaging study with 532 neuropathological correlates. European Journal of Neurology 19:1355-1360.

533 De Reuck JL (2012): The significance of small cerebral bleeds in neurodegenerative dementia 534 syndromes. Aging Dis 3:307-312.

535 De Reuck JL, Deramecourt V, Cordonnier C, Leys D, Pasquier F, Maurage CA (2012b): 
Tuovinen et al.

536 Cerebrovascular Lesions in Patients with Frontotemporal Lobar Degeneration: A

537 Neuropathological Study. Neurodegenerative Diseases 9:170-175.

538 Ding Z, Huang Y, Bailey SK, Gao Y, Cutting LE, Rogers BP, Newton AT, Gore JC (2018):

539 Detection of synchronous brain activity in white matter tracts at rest and under functional

540 loading. Proc Natl Acad Sci USA 115:595-600.

541 Dreha-Kulaczewski S, Joseph AA, Merboldt K-D, Ludwig H-C, Gartner J, Frahm J (2015):

542 Inspiration Is the Major Regulator of Human CSF Flow. Journal of Neuroscience 35:24855432491.

544 Du AT, Jahng GH, Hayasaka S, Kramer JH, Rosen HJ, Gorno-Tempini ML, Rankin KP, 545 Miller BL, Weiner MW, Schuff N (2006): Hypoperfusion in frontotemporal dementia and 546 Alzheimer disease by arterial spin labeling MRI. Neurology 67:1215-1220.

547 Erdő F, Denes L, de Lange E (2017): Age-associated physiological and pathological changes 548 at the blood-brain barrier: A review. Journal of Cerebral Blood Flow \& Metabolism 37:4-24.

549 Farb NAS, Grady CL, Strother S, Tang-Wai DF, Masellis M, Black S, Freedman M, Pollock 550 BG, Campbell KL, Hasher L, Chow TW (2013): Abnormal network connectivity in 551 frontotemporal dementia: Evidence for prefrontal isolation. Cortex 49:1856-1873.

552 Filippi M, Agosta F, Scola E, Canu E, Magnani G, Marcone A, Valsasina P, Caso F, Copetti 553 M, Comi G, Cappa SF, Falini A (2013): Functional network connectivity in the behavioral 554 variant of frontotemporal dementia. Cortex 49:2389-2401.

555 Fleisher AS, Podraza KM, Bangen KJ, Taylor C, Sherzai A, Sidhar K, Liu TT, Dale AM, 556 Buxton RB (2009): Cerebral perfusion and oxygenation differences in Alzheimer's disease 557 risk. Neurobiology of Aging 30:1737-1748.

558 Fonov V, Evans AC, Botteron K, Almli CR, McKinstry RC, Collins DL (2011): Unbiased 
Tuovinen et al.

average age-appropriate atlases for pediatric studies. NeuroImage 54:313-327.

Fonov V, Evans A, McKinstry R, Almli C, Collins D (2009): Unbiased nonlinear average age-appropriate brain templates from birth to adulthood. NeuroImage 47:S102.

Garrett DD, Kovacevic N, McIntosh AR, Grady CL (2010): Blood Oxygen Level-Dependent

Signal Variability Is More than Just Noise. Journal of Neuroscience 30:4914-4921.

Garrett DD, Kovacevic N, McIntosh AR, Grady CL (2011): The Importance of Being

Variable. Journal of Neuroscience 31:4496-4503.

Garrett DD, Lindenberger U, Hoge RD, Gauthier CJ (2017): Age differences in brain signal variability are robust to multiple vascular controls. Scientific Reports 7. http://www.nature.com/articles/s41598-017-09752-7.

Garrett DD, Nagel IE, Preuschhof C, Burzynska AZ, Marchner J, Wiegert S, Jungehülsing adults. Proceedings of the National Academy of Sciences 112:7593-7598.

CL (2013): Moment-to-moment brain signal variability: A next frontier in human brain mapping? Neuroscience \& Biobehavioral Reviews 37:610-624.

Gawryluk JR, Mazerolle EL, D'Arcy RCN (2014): Does functional MRI detect activation in white matter? A review of emerging evidence, issues, and future directions. Front Neurosci $8: 239$. 
Tuovinen et al.

582 Glomb K, Ponce-Alvarez A, Gilson M, Ritter P, Deco G (2018): Stereotypical modulations in 583 dynamic functional connectivity explained by changes in BOLD variance. NeuroImage $584 \quad 171: 40-54$.

585 Goel V, Stollstorff M, Nakic M, Knutson K, Grafman J (2009): A role for right ventrolateral 586 prefrontal cortex in reasoning about indeterminate relations. Neuropsychologia 47:27905872797.

Good CD, Johnsrude IS, Ashburner J, Henson RNA, Friston KJ, Frackowiak RSJ (2001): A Voxel-Based Morphometric Study of Ageing in 465 Normal Adult Human Brains. NeuroImage 14:21-36.

Grady CL, Garrett DD (2014): Understanding variability in the BOLD signal and why it matters for aging. Brain Imaging and Behavior 8:274-283.

Grady CL, Garrett DD (2018): Brain signal variability is modulated as a function of internal and external demand in younger and older adults. NeuroImage 169:510-523.

Greicius MD, Srivastava G, Reiss AL, Menon V (2004): Default-mode network activity (2015): Effective artifact removal in resting state fMRI data improves detection of DMN

600 functional connectivity alteration in Alzheimer's disease. Frontiers in Human Neuroscience 9. 601 http://journal.frontiersin.org/Article/10.3389/fnhum.2015.00449/abstract.

602 Guitart-Masip M, Salami A, Garrett D, Rieckmann A, Lindenberger U, Bäckman L (2016):

603 BOLD Variability is Related to Dopaminergic Neurotransmission and Cognitive Aging. 604 Cerebral Cortex 26:2074-2083. 
Tuovinen et al.

605 Hafkemeijer A, van der Grond J, Rombouts SARB (2012): Imaging the default mode network

606 in aging and dementia. Biochimica et Biophysica Acta (BBA) - Molecular Basis of Disease

$607 \quad 1822: 431-441$.

608 Hartikainen P, Räsänen J, Julkunen V, Niskanen E, Hallikainen M, Kivipelto M, Vanninen R, 609 Remes AM, Soininen H (2012): Cortical thickness in frontotemporal dementia, mild cognitive 610 impairment, and Alzheimer's disease. J Alzheimers Dis 30:857-874.

611 Hoge RD, Atkinson J, Gill B, Crelier GR, Marrett S, Pike GB (1999): Investigation of BOLD

612 signal dependence on cerebral blood flow and oxygen consumption: the deoxyhemoglobin

613 dilution model. Magn Reson Med 42:849-863.

614 Holtzman DM, Goate A, Kelly J, Sperling R (2011): Mapping the road forward in 615 Alzheimer's disease. Sci Trans1 Med 3:114ps48.

616 Hutchings R, Palermo R, Bruggemann J, Hodges JR, Piguet O, Kumfor F (2018): Looking

617 but not seeing: Increased eye fixations in behavioural-variant frontotemporal dementia.

618 Cortex 103:71-81.

619 Iidaka T, Sadato N, Yamada H, Yonekura Y (2000): Functional asymmetry of human 620 prefrontal cortex in verbal and non-verbal episodic memory as revealed by fMRI. Brain Res 621 Cogn Brain Res 9:73-83.

622 Iliff JJ, Chen MJ, Plog BA, Zeppenfeld DM, Soltero M, Yang L, Singh I, Deane R, 623 Nedergaard M (2014): Impairment of Glymphatic Pathway Function Promotes Tau Pathology 624 after Traumatic Brain Injury. The Journal of Neuroscience 34:16180-16193.

625 Iliff JJ, Goldman SA, Nedergaard M (2015): Implications of the discovery of brain lymphatic 626 pathways. The Lancet Neurology 14:977-979.

627 Iliff JJ, Wang M, Liao Y, Plogg BA, Peng W, Gundersen GA, Benveniste H, Vates GE, 
Tuovinen et al.

628 Deane R, Goldman SA, Nagelhus EA, Nedergaard M (2012): A paravascular pathway

629 facilitates CSF flow through the brain parenchyma and the clearance of interstitial solutes,

630 including amyloid $\beta$. Sci Transl Med 4:147ra111.

631 Iliff JJ, Wang M, Zeppenfeld DM, Venkataraman A, Plog BA, Liao Y, Deane R, Nedergaard

632 M (2013): Cerebral arterial pulsation drives paravascular CSF-interstitial fluid exchange in

633 the murine brain. J Neurosci 33:18190-18199.

634 Jahanian H, Ni WW, Christen T, Moseley ME, Tamura MK, Zaharchuk G (2014):

635 Spontaneous BOLD Signal Fluctuations in Young Healthy Subjects and Elderly Patients with

636 Chronic Kidney Disease. Ed. Yoko Hoshi. PLoS ONE 9:e92539.

637 Jenkinson M, Bannister P, Brady M, Smith S (2002): Improved Optimization for the Robust

638 and Accurate Linear Registration and Motion Correction of Brain Images. NeuroImage

$639 \quad 17: 825-841$.

640 Jenkinson M, Smith S (2001): A global optimisation method for robust affine registration of

641 brain images. Medical Image Analysis 5:143-156.

642 Keilholz SD, Pan W-J, Billings J, Nezafati M, Shakil S (2017): Noise and non-neuronal

643 contributions to the BOLD signal: applications to and insights from animal studies.

644 NeuroImage 154:267-281.

645 Khalil AA, Ostwaldt A-C, Nierhaus T, Ganeshan R, Audebert HJ, Villringer K, Villringer A,

646 Fiebach JB (2017): Relationship Between Changes in the Temporal Dynamics of the Blood-

647 Oxygen-Level-Dependent Signal and Hypoperfusion in Acute Ischemic Stroke. Stroke $648 \quad 48: 925-931$.

649 Kiviniemi V, Ruohonen J, Tervonen O (2005): Separation of physiological very low 650 frequency fluctuation from aliasing by switched sampling interval fMRI scans. Magn Reson 
Tuovinen et al.

Imaging 23:41-46.

652 Kiviniemi V, Wang X, Korhonen V, Keinänen T, Tuovinen T, Autio J, LeVan P, Keilholz S,

653 Zang Y-F, Hennig J, Nedergaard M (2016): Ultra-fast magnetic resonance encephalography

654 of physiological brain activity - Glymphatic pulsation mechanisms? J Cereb Blood Flow

655 Metab 36:1033-1045.

656 Kress BT, Iliff JJ, Xia M, Wang M, Wei HS, Zeppenfeld D, Xie L, Kang H, Xu Q, Liew JA,

657 Plog BA, Ding F, Deane R, Nedergaard M (2014): Impairment of paravascular clearance 658 pathways in the aging brain. Ann Neurol 76:845-861.

659 Lee SE, Khazenzon AM, Trujillo AJ, Guo CC, Yokoyama JS, Sha SJ, Takada LT, Karydas 660 AM, Block NR, Coppola G, Pribadi M, Geschwind DH, Rademakers R, Fong JC, Weiner 661 MW, Boxer AL, Kramer JH, Rosen HJ, Miller BL, Seeley WW (2014): Altered network 662 connectivity in frontotemporal dementia with C9orf72 hexanucleotide repeat expansion. Brain $663 \quad 137: 3047-3060$.

664 de Leon MJ, Li Y, Okamura N, Tsui WH, Saint Louis LA, Glodzik L, Osorio RS, Fortea J, 665 Butler T, Pirraglia E, Fossati S, Kim H-J, Carare RO, Nedergaard M, Benveniste H, Rusinek 666 H (2017): CSF clearance in Alzheimer Disease measured with dynamic PET. J Nucl Med.

667 Li S-J, Li Z, Wu G, Zhang M-J, Franczak M, Antuono PG (2002): Alzheimer Disease: 668 evaluation of a functional MR imaging index as a marker. Radiology 225:253-259.

669 Liu X, Chang C, Duyn JH (2013): Decomposition of spontaneous brain activity into distinct 670 fMRI co-activation patterns. Frontiers in Systems Neuroscience 7. 671 http://journal.frontiersin.org/Journal/10.3389/fnsys.2013.00101/full.

672 Louveau A, Da Mesquita S, Kipnis J (2016): Lymphatics in Neurological Disorders: A 673 Neuro-Lympho-Vascular Component of Multiple Sclerosis and Alzheimer's Disease? Neuron 
Tuovinen et al.

674

676

678

679

680

681

682

683

684

685

686

687

688

689

690

691

692

693

694

695

696

91:957-973.

Mackenzie IRA, Neumann M, Bigio EH, Cairns NJ, Alafuzoff I, Kril J, Kovacs GG, Ghetti B, Halliday G, Holm IE, Ince PG, Kamphorst W, Revesz T, Rozemuller AJM, Kumar-Singh S, Akiyama H, Baborie A, Spina S, Dickson DW, Trojanowski JQ, Mann DMA (2010): Nomenclature and nosology for neuropathologic subtypes of frontotemporal lobar degeneration: an update. Acta Neuropathol 119:1-4.

Makedonov I, Black SE, MacIntosh BJ (2013): BOLD fMRI in the White Matter as a Marker of Aging and Small Vessel Disease. Ed. Linda Chao. PLoS ONE 8:e67652.

Makedonov I, Chen JJ, Masellis M, MacIntosh BJ (2016): Physiological fluctuations in white matter are increased in Alzheimer's disease and correlate with neuroimaging and cognitive biomarkers. Neurobiology of Aging 37:12-18.

Mark CI, Mazerolle EL, Chen JJ (2015): Metabolic and vascular origins of the BOLD effect: Implications for imaging pathology and resting-state brain function. J Magn Reson Imaging 42:231-246.

Martin BA, Reymond P, Novy J, Balédent O, Stergiopulos N (2012): A coupled hydrodynamic model of the cardiovascular and cerebrospinal fluid system. American Journal of Physiology-Heart and Circulatory Physiology 302:H1492-H1509.

McIntosh AR, Kovacevic N, Lippe S, Garrett D, Grady C, Jirsa V (2010): The development of a noisy brain. Arch Ital Biol 148:323-337.

McKhann G, Drachman D, Folstein M, Katzman R, Price D, Stadlan EM (1984): Clinical diagnosis of Alzheimer's disease: Report of the NINCDS-ADRDA Work Group* under the auspices of Department of Health and Human Services Task Force on Alzheimer's Disease. Neurology 34:939-939. 
Tuovinen et al.

697 Neary D, Snowden JS, Gustafson L, Passant U, Stuss D, Black S, Freedman M, Kertesz A,

698 Robert PH, Albert M, Boone K, Miller BL, Cummings J, Benson DF (1998): Frontotemporal

699 lobar degeneration: A consensus on clinical diagnostic criteria. Neurology 51:1546-1554.

700 Nedergaard M (2013): Garbage Truck of the Brain. Science 340:1529-1530.

701 O’Callaghan J, Holmes H, Powell N, Wells JA, Ismail O, Harrison IF, Siow B, Johnson R,

702 Ahmed Z, Fisher A, Meftah S, O’Neill MJ, Murray TK, Collins EC, Shmueli K, Lythgoe MF

703 (2017): Tissue magnetic susceptibility mapping as a marker of tau pathology in Alzheimer's 704 disease. NeuroImage 159:334-345.

705 Olsson B, Lautner R, Andreasson U, Öhrfelt A, Portelius E, Bjerke M, Hölttä M, Rosén C,

706 Olsson C, Strobel G, Wu E, Dakin K, Petzold M, Blennow K, Zetterberg H (2016): CSF and

707 blood biomarkers for the diagnosis of Alzheimer's disease: a systematic review and meta-

708 analysis. The Lancet Neurology 15:673-684.

709 Özbay PS, Chang C, Picchioni D, Mandelkow H, Moehlman TM, Chappel-Farley MG, van

710 Gelderen P, de Zwart JA, Duyn JH (2018): Contribution of systemic vascular effects to fMRI

711 activity in white matter. Neuroimage 176:541-549.

712 Peer M, Nitzan M, Bick AS, Levin N, Arzy S (2017): Evidence for Functional Networks

713 within the Human Brain's White Matter. The Journal of Neuroscience 37:6394-6407.

714 Peng W, Achariyar TM, Li B, Liao Y, Mestre H, Hitomi E, Regan S, Kasper T, Peng S, Ding

715 F, Benveniste H, Nedergaard M, Deane R (2016): Suppression of glymphatic fluid transport

716 in a mouse model of Alzheimer's disease. Neurobiol Dis 93:215-225.

717 Plog BA, Dashnaw ML, Hitomi E, Peng W, Liao Y, Lou N, Deane R, Nedergaard M (2015):

718 Biomarkers of traumatic injury are transported from brain to blood via the glymphatic system.

719 J Neurosci 35:518-526. 
Tuovinen et al.

720 Plog BA, Nedergaard M (2018): The Glymphatic System in Central Nervous System Health

721 and Disease: Past, Present, and Future. Annual Review of Pathology: Mechanisms of Disease $722 \quad 13: 379-394$.

723 Rascovsky K, Hodges JR, Knopman D, Mendez MF, Kramer JH, Neuhaus J, van Swieten JC, 724 Seelaar H, Dopper EGP, Onyike CU, Hillis AE, Josephs KA, Boeve BF, Kertesz A, Seeley 725 WW, Rankin KP, Johnson JK, Gorno-Tempini M-L, Rosen H, Prioleau-Latham CE, Lee A, 726 Kipps CM, Lillo P, Piguet O, Rohrer JD, Rossor MN, Warren JD, Fox NC, Galasko D, 727 Salmon DP, Black SE, Mesulam M, Weintraub S, Dickerson BC, Diehl-Schmid J, Pasquier F, 728 Deramecourt V, Lebert F, Pijnenburg Y, Chow TW, Manes F, Grafman J, Cappa SF, 729 Freedman M, Grossman M, Miller BL (2011): Sensitivity of revised diagnostic criteria for the 730 behavioural variant of frontotemporal dementia. Brain 134:2456-2477.

731 Renton AE, Majounie E, Waite A, Simón-Sánchez J, Rollinson S, Gibbs JR, Schymick JC, 732 Laaksovirta H, van Swieten JC, Myllykangas L, Kalimo H, Paetau A, Abramzon Y, Remes 733 AM, Kaganovich A, Scholz SW, Duckworth J, Ding J, Harmer DW, Hernandez DG, Johnson 734 JO, Mok K, Ryten M, Trabzuni D, Guerreiro RJ, Orrell RW, Neal J, Murray A, Pearson J, 735 Jansen IE, Sondervan D, Seelaar H, Blake D, Young K, Halliwell N, Callister JB, Toulson G, 736 Richardson A, Gerhard A, Snowden J, Mann D, Neary D, Nalls MA, Peuralinna T, Jansson L, 737 Isoviita V-M, Kaivorinne A-L, Hölttä-Vuori M, Ikonen E, Sulkava R, Benatar M, Wuu J, 738 Chiò A, Restagno G, Borghero G, Sabatelli M, Heckerman D, Rogaeva E, Zinman L, 739 Rothstein JD, Sendtner M, Drepper C, Eichler EE, Alkan C, Abdullaev Z, Pack SD, Dutra A, 740 Pak E, Hardy J, Singleton A, Williams NM, Heutink P, Pickering-Brown S, Morris HR, 741 Tienari PJ, Traynor BJ (2011): A Hexanucleotide Repeat Expansion in C9ORF72 Is the 742 Cause of Chromosome 9p21-Linked ALS-FTD. Neuron 72:257-268.

743 Rueckert D, Sonoda LI, Hayes C, Hill DLG, Leach MO, Hawkes DJ (1999): Nonrigid 744 registration using free-form deformations: application to breast MR images. IEEE 
Tuovinen et al.

745 Transactions on Medical Imaging 18:712-721.

746 Ryan NS, Rossor MN, Fox NC (2015): Alzheimer's disease in the 100 years since

747 Alzheimer's death. Brain 138:3816-3821.

748 Rytty R, Nikkinen J, Paavola L, Abou Elseoud A, Moilanen V, Visuri A, Tervonen O, Renton

749 AE, Traynor BJ, Kiviniemi V, Remes AM (2013): GroupICA dual regression analysis of

750 resting state networks in a behavioral variant of frontotemporal dementia. Frontiers in Human

751 Neuroscience 7. http://journal.frontiersin.org/article/10.3389/fnhum.2013.00461/abstract.

752 Scarapicchia V, Mazerolle EL, Fisk JD, Ritchie LJ, Gawryluk JR (2018): Resting State

753 BOLD Variability in Alzheimer's Disease: A Marker of Cognitive Decline or

754 Cerebrovascular Status? Frontiers in Aging Neuroscience 10.

755 http://journal.frontiersin.org/article/10.3389/fnagi.2018.00039/full.

756 Seeley WW, Crawford RK, Zhou J, Miller BL, Greicius MD (2009): Neurodegenerative

757 diseases target large-scale human brain networks. Neuron 62:42-52.

758 Seeley WW, Menon V, Schatzberg AF, Keller J, Glover GH, Kenna H, Reiss AL, Greicius

759 MD (2007): Dissociable intrinsic connectivity networks for salience processing and executive

760 control. J Neurosci 27:2349-2356.

761 Seeley WW, Zhou J, Kim E-J (2012): Frontotemporal dementia: what can the behavioral

762 variant teach us about human brain organization? Neuroscientist 18:373-385.

763 Selkoe DJ (1991): The molecular pathology of Alzheimer's disease. Neuron 6:487-498.

764 Shmueli K, van Gelderen P, de Zwart JA, Horovitz SG, Fukunaga M, Jansma JM, Duyn JH

765 (2007): Low-frequency fluctuations in the cardiac rate as a source of variance in the resting-

766 state fMRI BOLD signal. Neuroimage 38:306-320. 
Tuovinen et al.

767 Shokri-Kojori E, Wang G-J, Wiers CE, Demiral SB, Guo M, Kim SW, Lindgren E, Ramirez

768 V, Zehra A, Freeman C, Miller G, Manza P, Srivastava T, De Santi S, Tomasi D, Benveniste

769 H, Volkow ND (2018): $\beta$-Amyloid accumulation in the human brain after one night of sleep

770 deprivation. Proc Natl Acad Sci USA 115:4483-4488.

771 Sjöbeck M, Haglund M, Englund E (2006): White matter mapping in Alzheimer’s disease: A 772 neuropathological study. Neurobiology of Aging 27:673-680.

Sled JG, Zijdenbos AP, Evans AC (1998): A nonparametric method for automatic correction of intensity nonuniformity in MRI data. IEEE Trans Med Imaging 17:87-97.

Smith S, Jenkinson M, Beckmann C, Miller K, Woolrich M (2007): Meaningful design and contrast estimability in FMRI. Neuroimage 34:127-136.

Smith SM (2002): Fast robust automated brain extraction. Human Brain Mapping 17:143155.

Smith SM, Nichols TE (2009): Threshold-free cluster enhancement: addressing problems of smoothing, threshold dependence and localisation in cluster inference. Neuroimage 44:83-98.

Snyder HM, Corriveau RA, Craft S, Faber JE, Greenberg SM, Knopman D, Lamb BT, contributions to cognitive impairment and dementia including Alzheimer's disease. Alzheimers Dement 11:710-717. 
Tuovinen et al.

790 Tartaglia MC, Rosen HJ, Miller BL (2011): Neuroimaging in Dementia. Neurotherapeutics

$791 \quad 8: 82-92$.

792 Toledo JB, Arnold SE, Raible K, Brettschneider J, Xie SX, Grossman M, Monsell SE, Kukull

793 WA, Trojanowski JQ (2013): Contribution of cerebrovascular disease in autopsy confirmed

794 neurodegenerative disease cases in the National Alzheimer's Coordinating Centre. Brain

$795 \quad 136: 2697-2706$.

796 Tosto G, Zimmerman ME, Carmichael OT, Brickman AM, Alzheimer's Disease

797 Neuroimaging Initiative (2014): Predicting aggressive decline in mild cognitive impairment:

798 the importance of white matter hyperintensities. JAMA Neurol 71:872-877.

799 Tracy TE, Gan L (2018): Tau-mediated synaptic and neuronal dysfunction in

800 neurodegenerative disease. Current Opinion in Neurobiology 51:134-138.

801 Triantafyllou C, Hoge RD, Krueger G, Wiggins CJ, Potthast A, Wiggins GC, Wald LL

802 (2005): Comparison of physiological noise at $1.5 \mathrm{~T}, 3 \mathrm{~T}$ and $7 \mathrm{~T}$ and optimization of fMRI

803 acquisition parameters. NeuroImage 26:243-250.

804 Tuovinen T, Rytty R, Moilanen V, Abou Elseoud A, Veijola J, Remes AM, Kiviniemi VJ

805 (2017): The Effect of Gray Matter ICA and Coefficient of Variation Mapping of BOLD Data

806 on the Detection of Functional Connectivity Changes in Alzheimer's Disease and bvFTD.

807 Frontiers $\quad$ in $\quad$ Human 10.

808 http://journal.frontiersin.org/article/10.3389/fnhum.2016.00680/full.

809 Wang HH, Menezes NM, Zhu MW, Ay H, Koroshetz WJ, Aronen HJ, Karonen JO, Liu Y,

810 Nuutinen J, Wald LL, Sorensen AG (2008): Physiological noise in MR images: An indicator

811 of the tissue response to ischemia? Journal of Magnetic Resonance Imaging 27:866-871.

812 Wang M, Norman JE, Srinivasan VJ, Rutledge JC (2016): Metabolic, inflammatory, and 
Tuovinen et al.

813 microvascular determinants of white matter disease and cognitive decline. Am J

814 Neurodegener Dis 5:171-177.

815 Whitwell JL, Josephs KA (2012): Recent Advances in the Imaging of Frontotemporal

816 Dementia. Current Neurology and Neuroscience Reports 12:715-723.

817 Wise RG, Ide K, Poulin MJ, Tracey I (2004): Resting fluctuations in arterial carbon dioxide

818 induce significant low frequency variations in BOLD signal. Neuroimage 21:1652-1664.

819 Wong S, Flanagan E, Savage G, Hodges JR, Hornberger M (2014): Contrasting Prefrontal

820 Cortex Contributions to Episodic Memory Dysfunction in Behavioural Variant

821 Frontotemporal Dementia and Alzheimer's Disease. Ed. Linda Chao. PLoS ONE 9:e87778.

822 Xie L, Kang H, Xu Q, Chen MJ, Liao Y, Thiyagarajan M, O’Donnell J, Christensen DJ,

823 Nicholson C, Iliff JJ, Takano T, Deane R, Nedergaard M (2013): Sleep Drives Metabolite

824 Clearance from the Adult Brain. Science 342:373-377.

825 Zhou J, Greicius MD, Gennatas ED, Growdon ME, Jang JY, Rabinovici GD, Kramer JH,

826 Weiner M, Miller BL, Seeley WW (2010): Divergent network connectivity changes in

827 behavioural variant frontotemporal dementia and Alzheimer's disease. Brain 133:1352-1367.

828 van der Zwaag W, Francis S, Head K, Peters A, Gowland P, Morris P, Bowtell R (2009):

829 fMRI at 1.5, 3 and 7 T: characterising BOLD signal changes. Neuroimage 47:1425-1434. 
bioRxiv preprint doi: https://doi.org/10.1101/455683; this version posted October 29, 2018. The copyright holder for this preprint (which was not certified by peer review) is the author/funder, who has granted bioRxiv a license to display the preprint in perpetuity. It is made available under aCC-BY 4.0 International license.

Tuovinen et al.

832 Tables

833

834 Table 1. Descriptive characteristics of the study groups in local institute data.

\begin{tabular}{llll}
\hline Local institute data & Controls & AD & bvFTD \\
\hline Participants & 24 & 17 & 18 \\
Age $(\mathrm{yrs})$ & $60.0 \pm 5.1$ & $60.0 \pm 5.4$ & $60.2 \pm 7.3$ \\
Female & $12(50 \%)$ & $11(65 \%)$ & $9(50 \%)$ \\
$\begin{array}{l}\text { Disease } \\
\text { (yrs) }\end{array}$ & - & $2.6 \pm 1.3$ & $2.9 \pm 1.9$ \\
MMSE & $29.0 \pm 1.1 *$ & $23.0 \pm 2.6$ & $24.2 \pm 4.1$ \\
FBI & $\mathrm{NC}$ & $\mathrm{NC}$ & $23.5 \pm 4.7$ \\
BDI & $3.2 \pm 3.3$ & $\mathrm{NC}$ & $\mathrm{NC}$
\end{tabular}

Medication

$\begin{array}{llll}\text { Memantine } & 0 & 2 & 3\end{array}$

$\begin{array}{llll}\text { Acetylcholin- } & 0 & 14 & 5\end{array}$

esterase inhibitors

$\begin{array}{llll}\text { Neuroleptic } & 0 & 4 & 8\end{array}$

$\begin{array}{llll}\text { Valproate } & 0 & 0 & 4\end{array}$

835

836 Values represent mean $\pm \mathrm{SD}$ or $\mathrm{N}(\%) . \mathrm{AD}=$ Alzheimer's disease. bvFTD $=$ behavioral variant 837 frontotemporal dementia. MMSE = Mini Mental State Examination (maximum total score is 30). FBI

$838=$ Frontal Behavioral Inventory Score (maximum total score is 72 ). BDI $=$ Beck's Depression 839 Inventory (maximum total score is 63 ). $\mathrm{NC}=$ not collected. $* \mathrm{p}<0.05$. 
bioRxiv preprint doi: https://doi.org/10.1101/455683; this version posted October 29, 2018. The copyright holder for this preprint (which was not certified by peer review) is the author/funder, who has granted bioRxiv a license to display the preprint in perpetuity. It is made available under aCC-BY 4.0 International license.

Tuovinen et al.

843

844

845 Table 2. Descriptive characteristics of the study groups in ADNI data.

\begin{tabular}{|c|c|c|}
\hline ADNI data & Controls & $A D$ \\
\hline Participants & 40 & 30 \\
\hline Total rs-FMRI datasets & 87 & 63 \\
\hline $\begin{array}{lll}\begin{array}{l}\text { Average } \\
\text { participant }\end{array} & \text { visits } & \text { per } \\
& & \end{array}$ & 2.2 & 2.1 \\
\hline Age (yrs) & $72.7 \pm 4.3$ & $71.8 \pm 6.5$ \\
\hline Female & $25(62 \%)$ & $15(50 \%)$ \\
\hline MMSE & $29.0 \pm 1.3$ * & $21.9 \pm 3.6$ \\
\hline
\end{tabular}

846

847 Values represent mean $\pm \mathrm{SD}$ or $\mathrm{N}(\%) . \mathrm{AD}=$ Alzheimer's disease. MMSE $=$ Mini Mental State 848 Examination (maximum total score is 30 ). $* p<0.05$. 
bioRxiv preprint doi: https://doi.org/10.1101/455683; this version posted October 29, 2018. The copyright holder for this preprint (which was not certified by peer review) is the author/funder, who has granted bioRxiv a license to display the preprint in perpetuity. It is made available under aCC-BY 4.0 International license.

Tuovinen et al.

849

850

851 Table 3. Effect of motion.

\begin{tabular}{|c|c|c|c|c|}
\hline \multirow[b]{2}{*}{$\begin{array}{l}\text { Template } \\
\text { (ROI) }\end{array}$} & \multicolumn{2}{|c|}{$\begin{array}{l}\text { Absolute head } \\
\text { motion }\end{array}$} & \multicolumn{2}{|c|}{ Relative head motion } \\
\hline & $F(2,54)$ & $\begin{array}{r}\text { Sig. } \\
\text { (p-value) }\end{array}$ & $F(2,54)$ & $\begin{array}{r}\text { Sig. } \\
\text { (p-value) }\end{array}$ \\
\hline WM & 10.089 & 0.000189 & 9.584 & 0.000274 \\
\hline GM & 15.006 & 0.000007 & 15.32 & 0.000005 \\
\hline CSF & 7.191 & 0.002 & 6.023 & 0.004 \\
\hline
\end{tabular}

852

853

Results of the ANCOVA analysis (local data). There is a statistically significant difference between different study groups on the mean $\mathrm{CV}_{\mathrm{BOLD}}$ values in different ROIs $(\mathrm{GM}=$ gray matter, $\mathrm{WM}=\mathrm{white}$ matter, CSF = cerebrospinal fluid) even when controlling for absolute or relative head motion parameters.

857

858

859

860

861

862

863

864

865

866

867

868

869

870

871

872

873 
bioRxiv preprint doi: https://doi.org/10.1101/455683; this version posted October 29, 2018. The copyright holder for this preprint (which was not certified by peer review) is the author/funder, who has granted bioRxiv a license to display the preprint in perpetuity. It is made available under aCC-BY 4.0 International license.

Tuovinen et al.

874

875

876 Table 4. Results of the ROC analysis.

\section{Local institute data $\quad$ ADNI data}

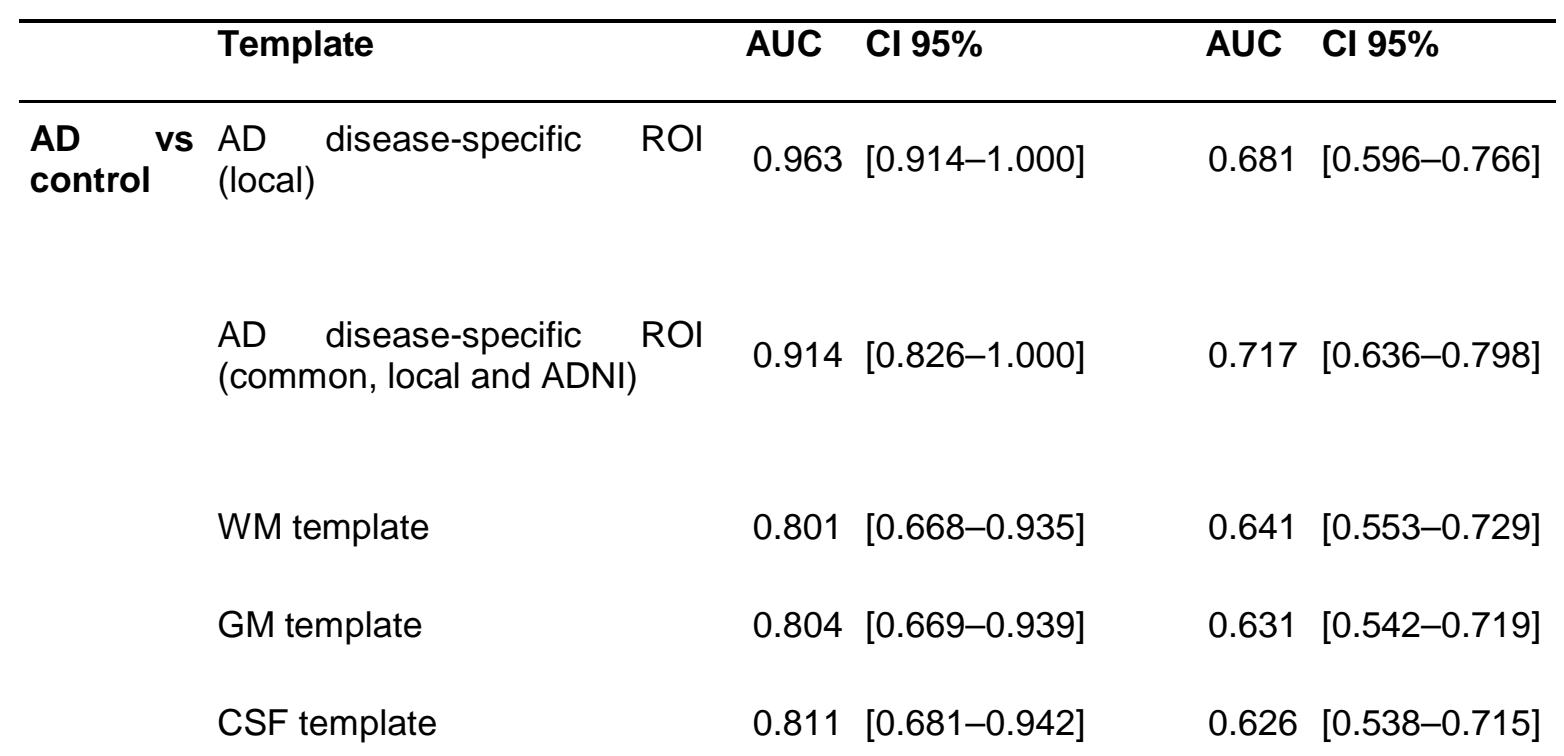

bvFTD vs control

bvFTD disease-specific ROI

$0.958[0.906-1.000]$

WM template

$0.846[0.725-0.966]$

GM template

$0.897[0.801-0.993]$

CSF template

$0.75[0.601-0.899]$

$\operatorname{AD}_{\text {bvFTD }}$ vs
$\begin{aligned} & \text { AD } \\ & \text { (local) }\end{aligned}$ disease-specific

bvFTD disease-specific ROI 0.197 [0.044-0.350]

877

$878 \mathrm{AD}=$ Alzheimer's disease. bvFTD $=$ behavioral variant frontotemporal dementia. AUC $=$ area under 879 the curve. $\mathrm{CI}=$ confidence interval. 
bioRxiv preprint doi: https://doi.org/10.1101/455683; this version posted October 29, 2018. The copyright holder for this preprint (which was not certified by peer review) is the author/funder, who has granted bioRxiv a license to display the preprint in perpetuity. It is made available under aCC-BY 4.0 International license.

Tuovinen et al.

Figures and legends

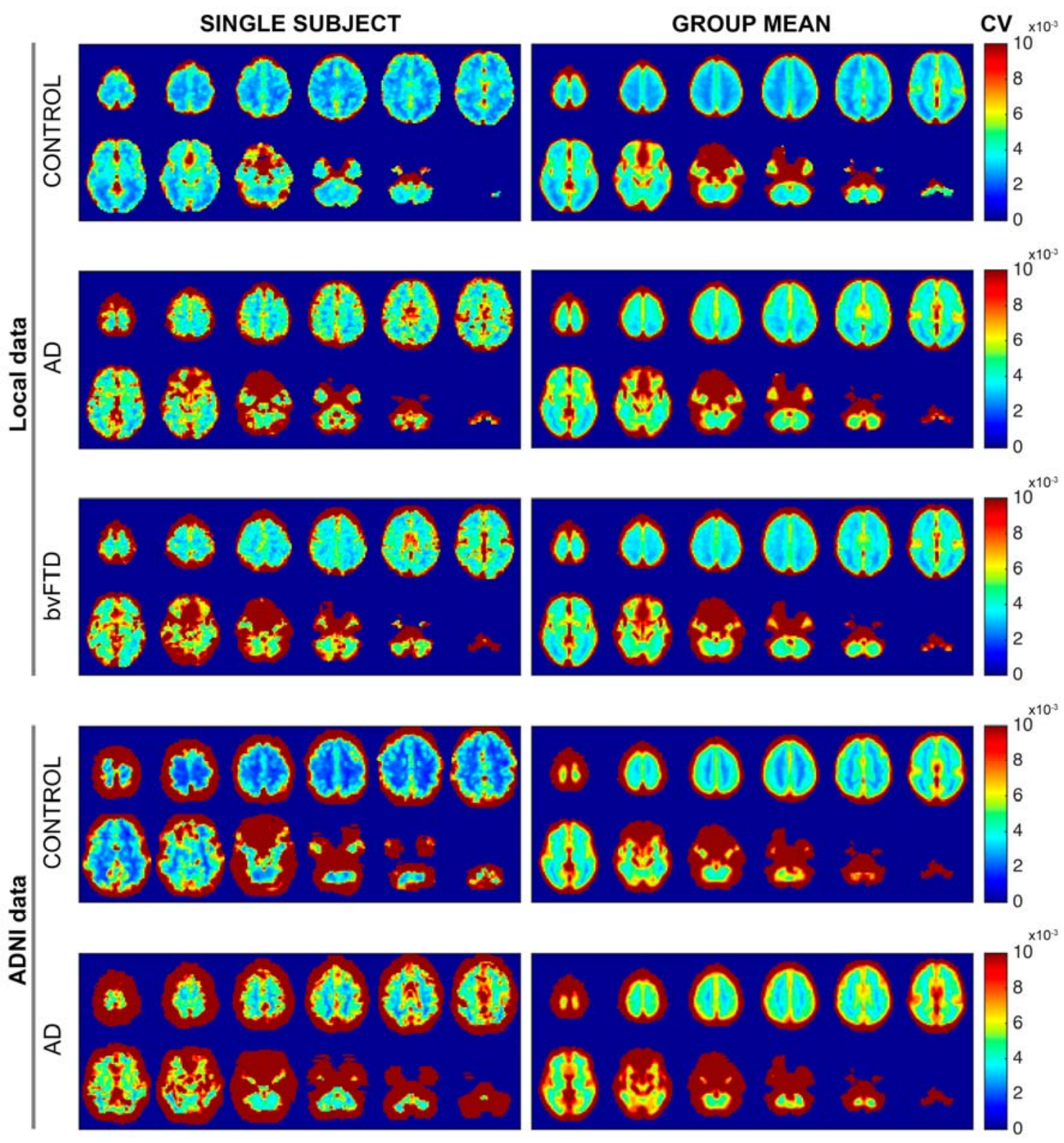

Fig. 1. Coefficient of variation mapping of BOLD signal. Examples of randomly selected single 
bioRxiv preprint doi: https://doi.org/10.1101/455683; this version posted October 29, 2018. The copyright holder for this preprint (which was not certified by peer review) is the author/funder, who has granted bioRxiv a license to display the preprint in perpetuity. It is made available under aCC-BY 4.0 International license.

Tuovinen et al.

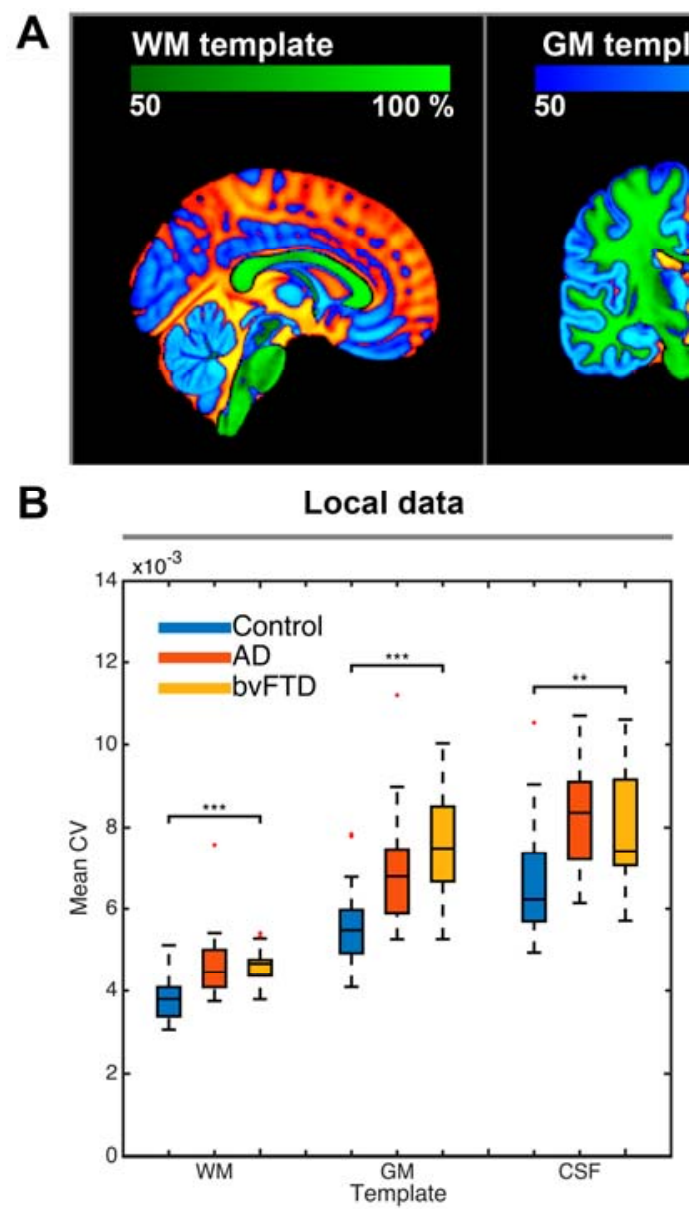

Fig. 2. Mean $\mathbf{C V}_{\text {BOLD }}$ values in GM, WM and CSF. On top is the ICBM152 template used as ROI for calculating mean $\mathrm{CV}_{\mathrm{BOLD}}$ values that are represented here as a boxplot with respective color encoding. Additional motion correction using despiking did not affect these results. 
bioRxiv preprint doi: https://doi.org/10.1101/455683; this version posted October 29, 2018. The copyright holder for this preprint (which was not certified by peer review) is the author/funder, who has granted bioRxiv a license to display the preprint in perpetuity. It is made available under aCC-BY 4.0 International license.

Local data
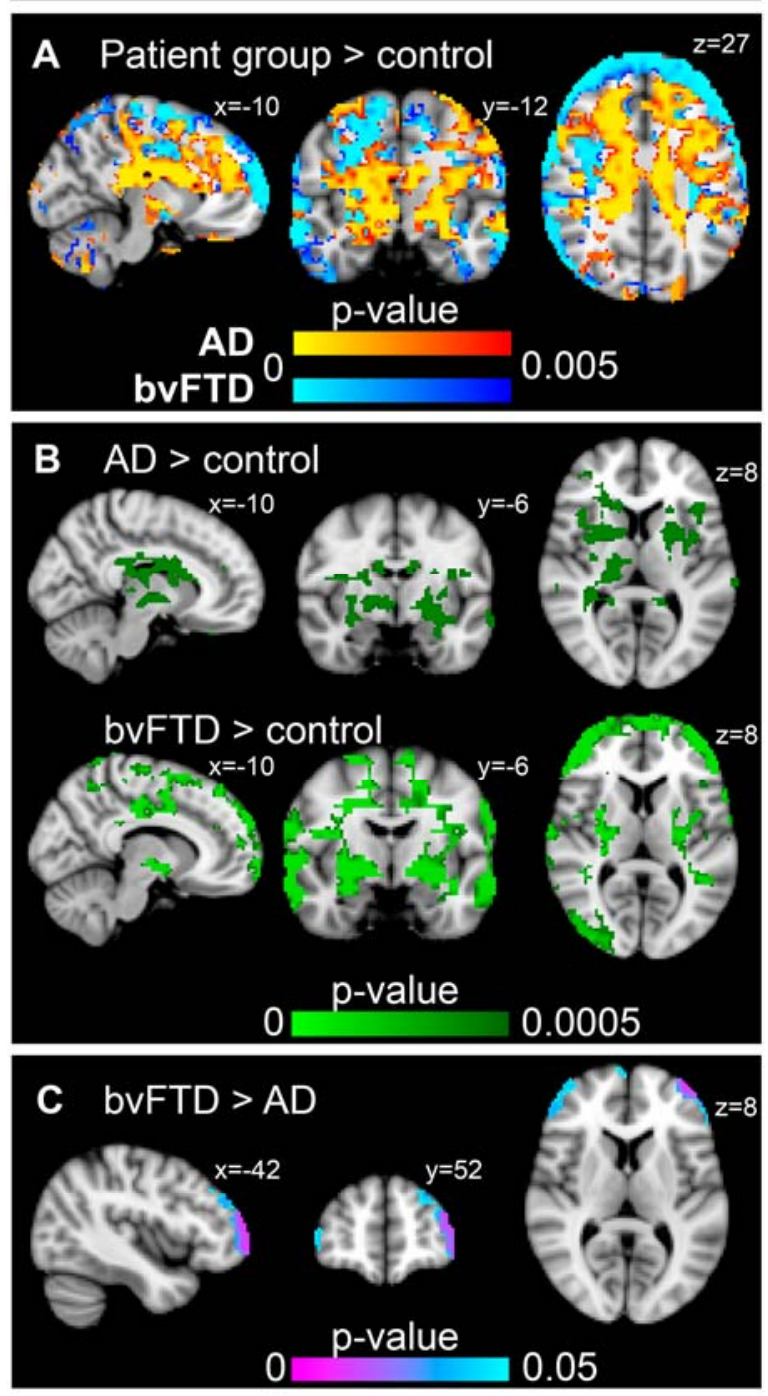

890 Fig. 3. Statistically significant voxel-wise $\mathbf{C V}_{\text {BOLD }}$ differences between study groups and their 891 TFCE-corrected p-values. $\mathrm{A}$ and $\mathrm{B}$ shows the AD and bvFTD results with different p-value 892 thresholds indicated in the image. In $\mathrm{C}$, the cluster of voxels is presented where $\mathrm{CV}_{\mathrm{BOLD}} \mathrm{values}_{\text {are }}$ higher in the bvFTD group vs. AD group. 
bioRxiv preprint doi: https://doi.org/10.1101/455683; this version posted October 29, 2018. The copyright holder for this preprint (which was not certified by peer review) is the author/funder, who has granted bioRxiv a license to display the preprint in perpetuity. It is made available under aCC-BY 4.0 International license.

Tuovinen et al.

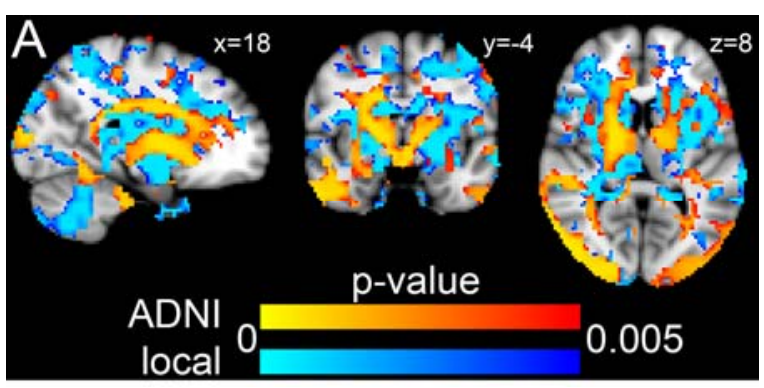

896

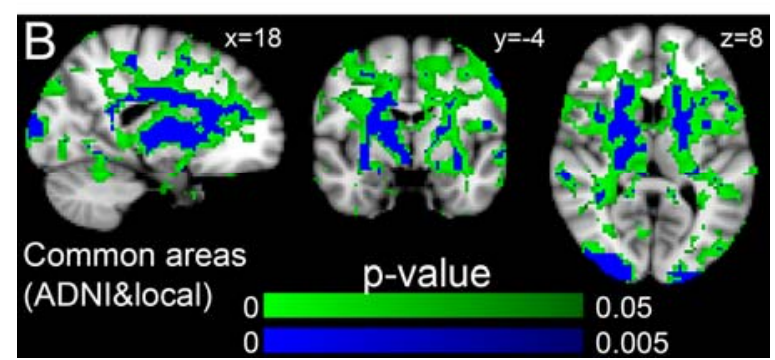

897 Fig. 4. Comparison of the voxel-wise $\mathbf{C V}_{\text {BOLD }}$ differences between local institute and ADNI data

898 (AD>control). B shows the common areas and mean p-value between local institute and ADNI data in

899 two different $p$-values $(p<0.05$ and $p<0.005$, TFCE-corrected for familywise errors). $56 \%$ of the statistically significant voxels $(\mathrm{p}<0.05)$ are shared in both data sets.

901

902

903

904

905

906 
bioRxiv preprint doi: https://doi.org/10.1101/455683; this version posted October 29, 2018. The copyright holder for this preprint (which was not certified by peer review) is the author/funder, who has granted bioRxiv a license to display the preprint in perpetuity. It is made available under aCC-BY 4.0 International license.

Tuovinen et al.
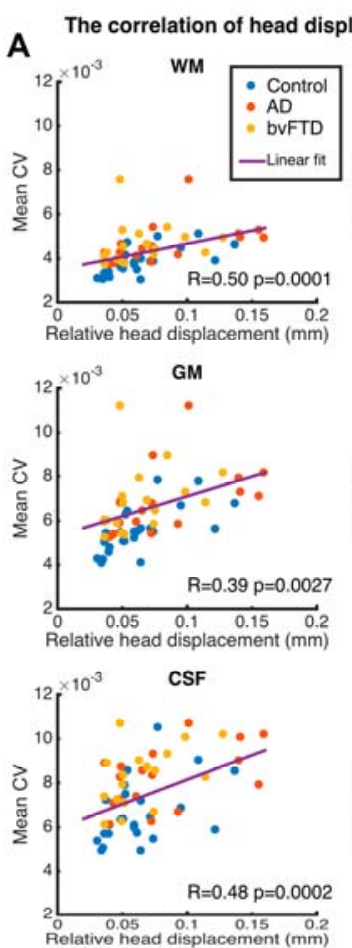
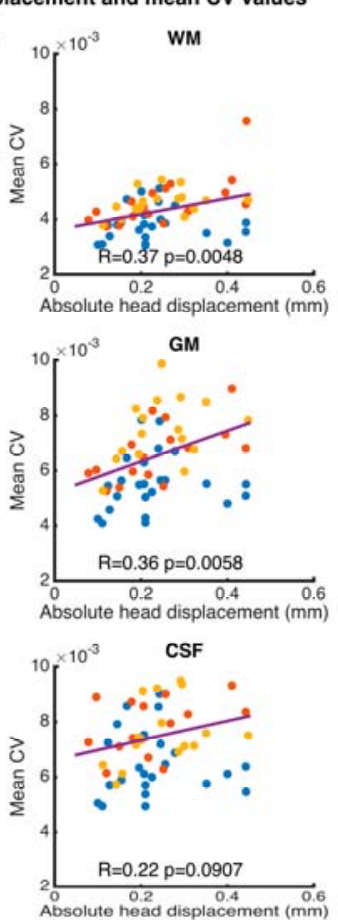
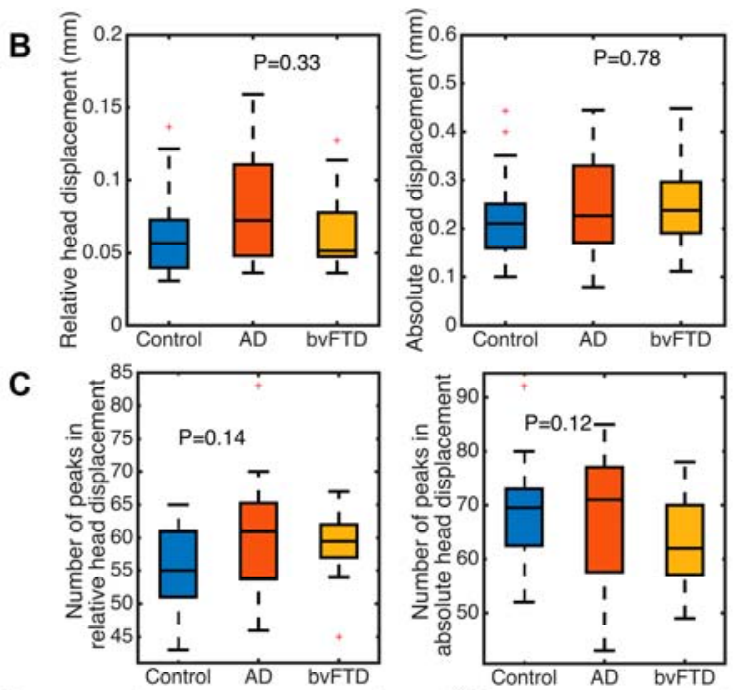

D
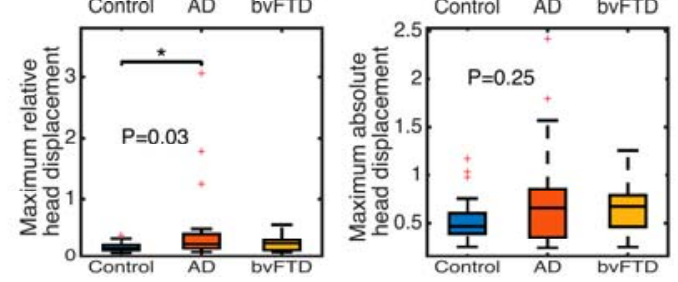

908

909

910

911

912

913

914

915

916

917

918

919

920

Fig. 5. Effect of motion on $\mathbf{C V}_{\text {BOLD }}$ values (local institute data). Scatter plot (A) for the mean $\mathrm{CV}_{\mathrm{BOLD}}$ value within template vs. head displacement (relative and absolute). Correlation between mean $\mathrm{CV}_{\mathrm{BOLD}}$ and head displacement is also shown. The mean $\mathrm{CV}_{\mathrm{BOLD}}$ values are higher in the patient groups (red and yellow circles) than in the control group (blue circles) with the same amount of motion both in the absolute and relative head displacement. Subject-wise absolute displacement values (in $\mathrm{mm}$ ) were extracted, describing the amount of movement in all directions over the whole scan as a marker of gross motion. Also, relative displacement values were extracted, as a marker of motion between each EPI volume. Boxplot of the mean absolute and relative head displacement is shown in B. Differences in subject-wise mean absolute and relative motion values with $\mathrm{CV}_{\mathrm{BOLD}}$ values were tested using Spearman's rank correlation coefficient. Additionally, a number of peaks (C) and the maximum value (D) in the subject-wise motion data were evaluated. 
bioRxiv preprint doi: https://doi.org/10.1101/455683; this version posted October 29, 2018. The copyright holder for this preprint (which was not certified by peer review) is the author/funder, who has granted bioRxiv a license to display the preprint in perpetuity. It is made available under aCC-BY 4.0 International license.

Tuovinen et al.

Local data
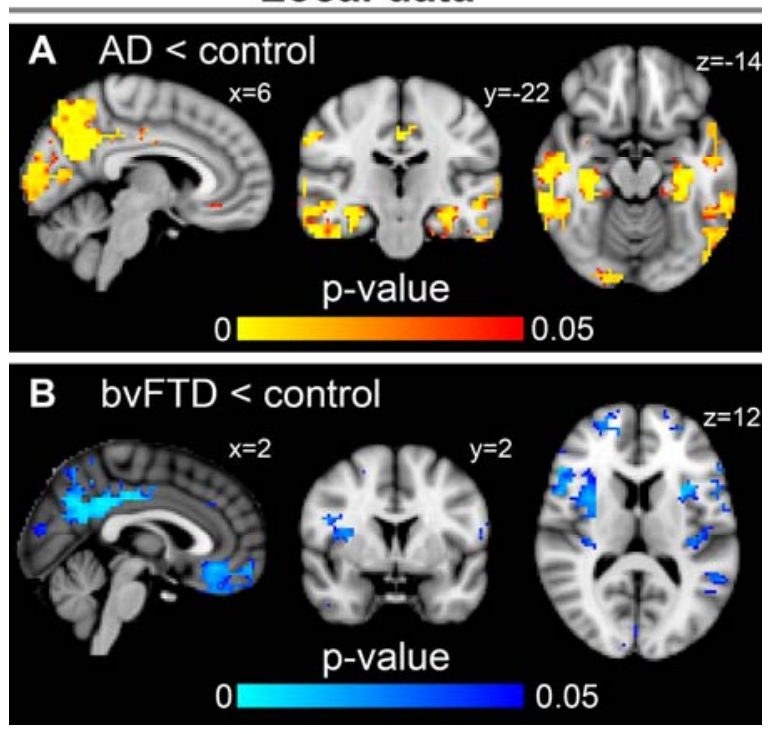

921

Fig. 6. Gray matter atrophy patterns when compared to controls (local institute data). In AD, the most prominent atrophy was detected in precuneus and posterior cingulate gyrus. Significant atrophy was also detected in other temporoparietal areas. In bvFTD, atrophy was detected in posterior cingulate gyrus and also in widespread frontotemporal areas and insula.

926 

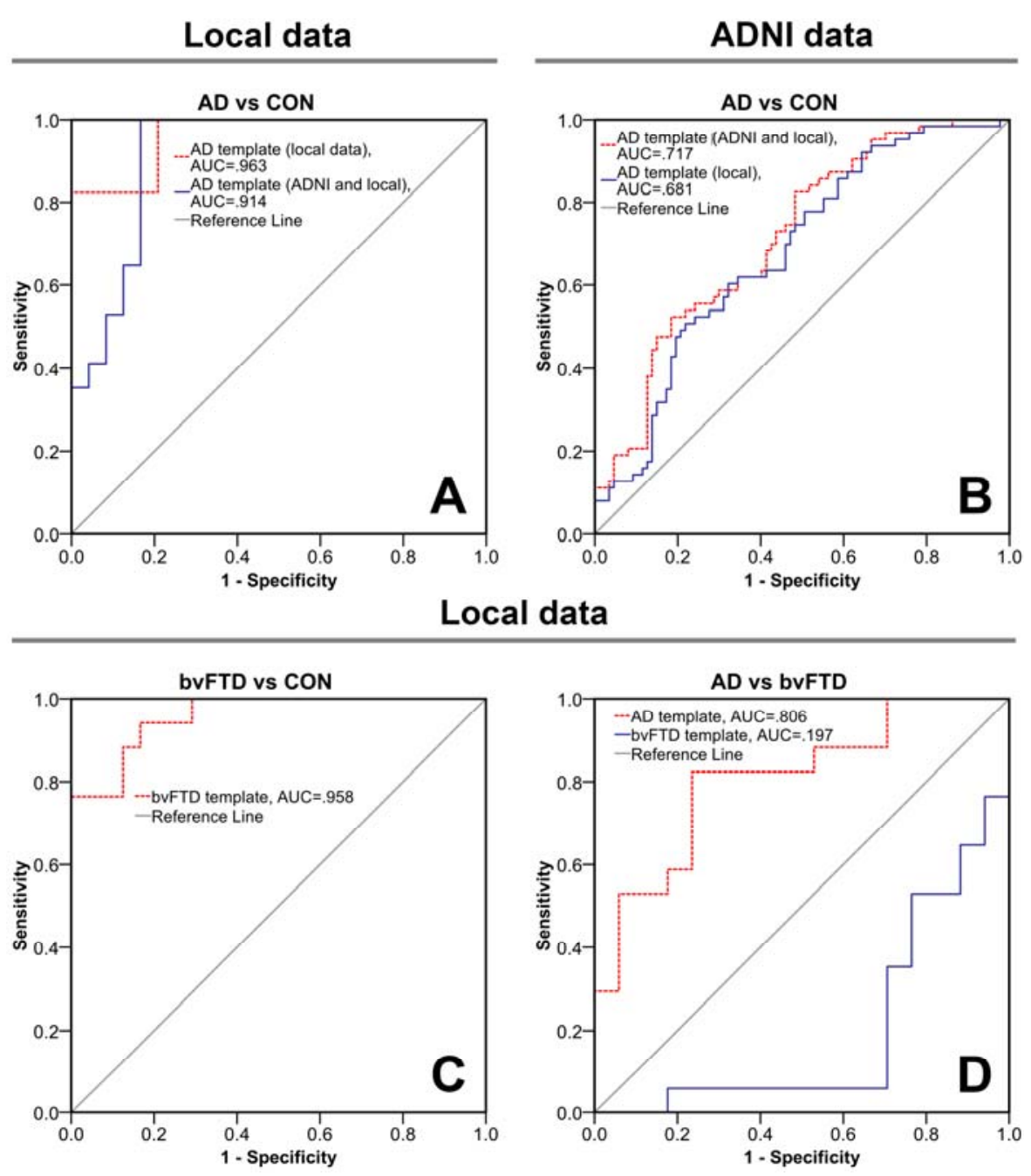

Fig. 7. Receiver operating characteristic (ROC) curves and area under the curve values (AUC, $\mathbf{p}<0.003$ ) for differential diagnosis based on mean $\mathrm{CV}_{\text {BOLD }}$ values within region-of-interest. $\mathrm{A}$, ROC curve for distinguishing patients with $A D$ from control subjects on the basis of $C V_{B O L D}$ values within $\mathrm{AD}$ template as ROI. Red lines represent the template created using the most significant differences $(p<0.0005)$ between groups in local data (Fig. 3B) and in blue the significant differences $(\mathrm{p}<0.005)$ common in both ADNI and local data (Fig. 4B). B, Same as in A for the ADNI data. C, ROC curve for distinguishing patients with bvFTD from control subjects on the basis of $\mathrm{CV}_{\text {BOLD }}$ values within the bvFTD template as ROI. The template for ROI was created using the most significant differences $(\mathrm{p}<0.0005)$ between groups in local data (Fig. 3B). D, ROC curve for distinguishing patients with bvFTD from those with $\mathrm{AD}$ on the basis of $\mathrm{AD}$ or bvFTD template. Confidence intervals are shown in Table 4. 